This is an electronic reprint of the original article. This reprint may differ from the original in pagination and typographic detail.

Author(s): Kipping, Matthias; Lamberg, Juha-Antti

Title: History in Process Organization Studies : What, why and how

Year: $\quad 2017$

Version:

Please cite the original version:

Kipping, M., \& Lamberg, J.-A. (2017). History in Process Organization Studies : What, why and how. In A. Langley, \& H. Tsoukas (Eds.), The SAGE Handbook of Process Organization Studies (pp. 303-319). Sage publications. https://doi.org/10.4135/9781473957954.n19

All material supplied via JYX is protected by copyright and other intellectual property rights, and duplication or sale of all or part of any of the repository collections is not permitted, except that material may be duplicated by you for your research use or educational purposes in electronic or print form. You must obtain permission for any other use. Electronic or print copies may not be offered, whether for sale or otherwise to anyone who is not an authorised user. 


\section{History in Process Organization Studies: What, why and how}

Muotoiltu: Taso 1, Riviväli: Kaksois

Muotoiltu: Riviväli: Kaksois

Matthias Kipping (mkipping@schulich.yorku.ca)

and

Juha-Antti Lamberg

\section{Abstract:}

The chapter highlights the versatile nature $-_{-}$in an onto-epistemological and methodological sense - ; of historical studiess; and the opportunities a proper historical approach could offer for process scholars. We suggest that such a $\underline{\text { A historical approach is }}$ particularly valuable when studyingstudying-processes located in the past or ; when studyingrelationships between processes and their outcomes. It also allows and whento considering other outcomes that were possible at the time and to -examineing why they did not materialize and what the consequences might have been if they had. We emphasize that the use of historical sources requires a very different type of philosophical stance towards reasoning compared to other social sciences and specific types of skills-and a very different Epe of philosophical stance towards reasoning compared to other social sciences. Thus, wEspecially, when making interpretations of the motives and logics of past actors, historians engage in an active reasoning process that results in historical descriptions and conclusions. As for the skills, wA histor is loced in the past; whenstudving relationships between prosesses and their outcomes: and when considering other outcomes that were possible at the time, examining why they did not materialize and what the consequences might have been if they had.We
Muotoiltu: Fontti: Lihavoitu Muotoiltu: Taso 1, Riviväli: Kaksois Muotoiltu: Riviväli: Kaksois
Muotoiltu: Tarkista oikeinkirjoitus ja kielioppi 
highlightpoint to the importance of source criticism, constant theorizing, and hermeneutic

treatment of materials in the making ofthe historical analyses of processes.

\section{Introduction} process analysis, the literature that actually does this is ratherlimited. Thus, in-depth analyses of organizational processes and even the broader notion of 'process' are almost entirely absent from the work of business historians ( $\mathrm{f}$. 2013). Similarly, process management scholars in general and organization theorists in particular have only rarely used history, in the sense of looking at past events and their outcomes. And the few exceptional cases are generally based on published data and/or retrospective interviews rather than primary sources drawn from the archives of the organizations studied (see-e.g. Vuori and Huy, 2015; $0 r_{2}$ for a rare exception of a process study based on archival sources, see-Wright and Zammuto, 2013). This has also been highlighted by Kipping and Üsdiken (2014) in their review of history in organization and management theory. While finding that history - either as data or as a theoretical construct - was used more extensively than widely assumed, they pinpointed process theorizing as a

There is great potential for a historical approach to process organization studies. On a general level, both historians and process scholars study processes that unfold over time. Yet, dDespite these similarities and the possible advantages of combining history and

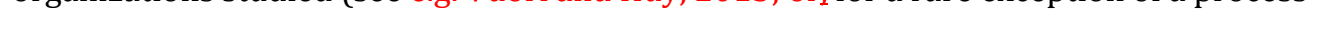

Muotoiltu: Taso 1, Riviväli: Kaksois

Muotoiltu: Riviväli: Kaksois

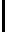


kind of blind spot - a research program with significant but largely unfulfilled potential for combining history and theory.

What explains this apparent scarcity of historical approaches to process organization studies? For business history, the reasons seem related to the predominant research questions, which tend to focus on what happened and why - rather than examining how it happened, which is central to process organization studies. Many business historians still aim to produce what Rowlinson, Hassard and Decker (2014: 260) refer to as a 'holistic objectivist narrative', 'conceptualized as a contribution to the totality of history, filling an important gap'. The result is apparent in a recent analysis of the articles published in two major business history journals - Business History and Business History Review, where the vast majority were descriptive case studies without explicit theory or methodology (de Jong, Higgins and van Driel, 2015). Overall, tit is rare to find papers adopting process perspectives in these journals.

By contrast, the scarcity of historical studies among process organization scholars seems to have its roots in methodological choices. Through their training, they are more familiar with other methodologies - in particular interviews and ethnography (e.g. Mueller et al., 2013; see also Chapters 14 and 15 in this volume). These also have the advantage of being widely accepted as legitimate within the community of management scholars and therefore make it easier to publish in the main journals of the management and organization field. Moreover, methodological handbooks in management and organization studies either completely ignore historical methods or offer little practical guidance. 
But despite this apparent reticence on both sides, there have actually been a number of studies based on a range of ontological and methodological approaches that do examine processes. The following section will briefly and systematically survey these studies, providing illustrative exemplars for the various approaches. Next, we make suggestions about when such historical studies might be particularly helpful for studying organizational processes, while also identifying potential pitfalls. Subsequently, we propose specific research strategies for implementing the historical approach to process organization studies.

\section{What has been done so far? Extant literatures}

\section{Structuring the review: Ontology and methodology}

Historical research is not a unified methodological approach that organizational scholars can simply activate and use. On the contrary, there is a long tradition of debate between different streams of historical research similar to the paradigm heterogeneity in organization studies in general (Burrell and Morgan, 1979). This is also reflected in recent discussions and overviews of business and organizational history as fields of study (see, e.g., Clark and Rowlinson, 2004; Decker, Kipping and Wadwhani, 2015; Ericson, Melin and Popp, forthcoming2015; Rowlinson, Hassard and Decker, 2014).
Muotoiltu: Taso 1, Riviväli: Kaksois

Muotoiltu: Riviväli: Kaksois

Muotoiltu: Taso 1, Riviväli: Kaksois

Muotoiltu: Riviväli: Kaksois 
To simplify the variety and complexity of these approaches, we suggest that their fundamental differences can be characterized along two dimensions. First, there is a distinction in terms of onto-epistemological paradigmatic differences between historical realism and constructivism, with the former considering historical evidence as a reflection of reality, while the latter sees narratives and discourses as the only or dominant from of reality. For a long time, different varieties of realism dominated the field, but at least since the 1970s, history has increasingly been written using varying degrees of social constructivism, with some taking a rather radical 'narrative' or 'linguistic' turn (e.g. White 1975). What should be noted here is that a large number of historians, and especially business and social science historians, remain 'some sort of realists' (Steinmetz, 1998: 69), despite what certain management and organizational historians believe or want to make believe about the constructivist and narrative nature of historical research (e.g. Clark and Rowlinson 2004; Durepos and Mills, 2012; McLaren, Mills and Weatherbee, 2015).

The second dimension reflects variations in the methodological techniques being used.

Many historians, and especially business historians, conduct research in a way that could be called 'interpretative', in the sense that the most important skills are related to source criticism and to the reasoning necessary to impose a logic that combines existing historical sources. While taking a different stance at the onto-epistemological level, many of those following a more constructivist approach also tend to conduct their research in an 'interpretative' way. At the other extreme of the methodological dimension, both the realist and constructivist approaches to history have attracted more formal, but not necessarily quantitative techniques, albeit drawing on different disciplinary origins. Hence, in realist 
research, formal methods have tended to come from historical sociology, while for constructivism, they have drawn on the formal analysis of texts in literature and critical studies. Figure 1 summarizes the origins and main features of the four resulting combinations. Each of them will be discussed in some more detail in the following subsections.

Figure 1. Four basic historical approaches

\begin{tabular}{|c|c|c|c|}
\hline \multirow{2}{*}{\multicolumn{2}{|c|}{$\boldsymbol{\Lambda},--\ldots-\ldots-\ldots-\ldots-\ldots--$}} & \multicolumn{2}{|c|}{ Methodological orientation } \\
\hline & & Interpretative & Formal-analytical \\
\hline $\begin{array}{l}\text { Onto- } \\
\text { episte } \\
\text { mologi } \\
\text { cal }\end{array}$ & $\begin{array}{l}\text { Constructivist: } \\
\text { Emphasis on } \\
\text { narratives as } \\
\text { only or dominant } \\
\text { reality }\end{array}$ & $\begin{array}{l}\text { NARRATIVIST } \\
\text { Historical process research } \\
\text { thatFfollows the 'narrative } \\
\text { turn' in argumentation and } \\
\text { style of reporting. Originates } \\
\text { in narrative philosophy and } \\
\text { methods in social sciences } \\
\text { aiming to avoid explicit } \\
\text { causal arguments (e.g. } \\
\text { Hansen, 20072007; } \\
\text { McKinlay, 2013) }\end{array}$ & $\begin{array}{l}\text { STRUCTURALIST } \\
\text { Historical process research } \\
\text { thatU uses the methods and } \\
\text { skills of formal narratological } \\
\text { researchers. Originates in } \\
\text { formalist and semiotic } \\
\text { research tradition in } \\
\text { humanities and social theory } \\
\text { (e.g. Lamberg and Pajunen, } \\
\text { 2005; Monin and Monin, } \\
2005 \text {; Sorensen, } \\
\text { 2008)Reveley, 2010) }\end{array}$ \\
\hline
\end{tabular}

Muotoiltu: Taso 1, Riviväli: Kaksois

Muotoiltu: englanti (Yhdysvallat) Muotoiltu: Riviväli: Kaksois

Muotoiltu: englanti (Yhdysvallat) Muotoiltu: Riviväli: Kaksois

Muotoiltu taulukko 


\begin{tabular}{|c|c|c|c|}
\hline $\begin{array}{l}\text { orienta } \\
\text { tion }\end{array}$ & $\begin{array}{l}\text { Realist: } \\
\text { Emphasis on } \\
\text { evidence and } \\
\text { stories as } \\
\text { representations } \\
\text { of reality }\end{array}$ & $\begin{array}{l}\text { (CON)SEQUENTIALIST } \\
\text { Focuses on sequences of } \\
\text { conditions, actions and } \\
\text { effects (Stinchcombe, } \\
\text { 2005)with with differentces } \\
\text { in terms of the degrees of } \\
\text { determinism to which } \\
\text { eutcomes are perceived as } \\
\text { determined_f-Some } \\
\text { historical process studies } \\
\text { (e.g. Chandler, }{ }_{2} \text { 1962; } \\
\text { Freeland }{ }_{2} 2001 \text { ); or looks at } \\
\text { external and internal } \\
\text { contexts in 'political' change } \\
\text { processes (e.g. Pettigrew, } \\
\text { 1985; Kipping and } \\
\text { Westerhuis, 2012) }\end{array}$ & $\begin{array}{l}\text { CAUSALIST } \\
\text { Draws on sSocial science } \\
\text { oriented research focusinged } \\
\text { on comparisons and formal } \\
\text { methods of process analysis } s_{-=} \\
\text {Originates in social science } \\
\text { history, and historical } \\
\text { sociology (e.g. Pajunen }{ }_{2} 2005_{\bar{L}} \\
2008 \text { ) }\end{array}$ \\
\hline
\end{tabular}

Muotoiltu: englanti (Yhdysvallat)

When conducting process organization research from a historical perspective, it is fundamental to keep all of these combinations and options in mind rather than reducing discussion to a single onto-epistemological position or one particular methodology. We believe this is important for a number of reasons. Firstof all, it correlates with the overall philosophical multi-vocality of process research (Langley, 1999; Rantakari and Vaara, 2016; Vaara and Lamberg, 2016). Importantly, it also reflects the above-described philosophical 
dichotomy among historians and social science historians between realism and constructivism. Second, by highlighting the fact that there exists more than one alternative for conducting historical research we continue a tradition in qualitative inquiry to match problems with methods (Langley, 1999), evoking different sets of opportunities for theoretical and historical work in process studies. Third, although the approaches are to some extent incommensurable and offer competing world-views, they are also complementary even with some authors combining different methodologies.

\section{Narrativist approaches}

Narrativist approaches combine a constructivist or post-structuralist (Kellner ${ }_{\llcorner} 1987$ )

ontology that sees historical sources as a reality in their own right with an interpretative, non-formal - often implicit rather than explicit - methodology. Among business historians such approaches have remained relatively rare - despite a number of studies, positing themselves as exemplars, such as the work by Hansen (2007) on the role of historical narratives in the organizational transformation of Danish savings banks. In management and organization studies, some management scholars, usually looking at field level changes (e.g. David, Sine and Haveman, 20130casio et al., 2016; David, Sine and Haveman, 201)3), have also used historical sources and made reference to historical methodology, namely to the work of Hayden White (e.g. 1975). Based on a similar narrativist view of historical research, Clark and Rowlinson (2004) have called for a more broad based 'historic turn' in organization studies - a call that has been answered so far only by a limited group of scholars in management and organizational history (see McLaren, Mills and Weatherbee, 2015). 


\section{(Clark and Rowlinson, 2004; Hansen, 2012) promote is not necessarily shared by}

mainstream historians, who would see 'proper history' as the result of an interpretative process where the researcher's role is conceived as a mechanism-link between the sources and the resulting text that typically has a strict narrative structure - a process that would, for instance, rely on Collingwood (19561946) as a philosophical starting point.

Collingwood's main idea was to see the researcher as re-constituting historical events both as a narrative description of past events and, more importantly, as re-enacting the 'inner thoughts' and psychological processes of past actors (see, for a more extensive discussion, Vaara and Lamberg, 2016).

A more recent methodological literature has promoted micro-history_i.e. studying processes by focusing on smallest analytical units and their social dynamics; fsee Melin et at.Ericson, Melin and Popp, 2015; Vaara and Lamberg, 20152016) as a promising avenue to re-vitalize 'non-technical' narrative research. However, while the rare examples of such research (e.g. Quinn 2001) provide descriptions of events and structures, they show much less if any interest in the thoughts, motives, and logics_of past actors. And not only do many of these studies examine processes in a rather broad sense, the vast majority also rely on limited historical evidence, often building on second-hand accounts and/or secondary sources (e.g. Haveman, Habinek and Goodmanet al., 2012; Raff, 2000). Neither do they generally follow the suggestion by Vaara and Lamberg (2016: 4) of examining "'-"the ways in which strategic processes and practices and our conceptions of them are embedded in, and
Kommentti [al1]: Can you clarify the difference between the two views of historical narratives (the one above and the one in this paragraph). I am sorry but it is not clear to me at the moment.

Muotoiltu: englanti (Yhdysvallat)
Muotoiltu: Tarkista oikeinkirjoitus ja kielioppi 
defined by, socio-historical environments.'-'- Another potential source of inspiration for historical narrativist research is Foucault's work, although again, most Foucauldian studies also do not draw on original archival sources. An exception is McKinlay's (2013) interesting examination of the largely invisible processes of accommodation or contestation by bank clerks in Victorian England based on a series of self-made cartoons.

\section{Structuralist approaches}

In the context of historical process studies, structuralist approaches, sometimes framed as narratological methods and defined as- 'the stucturalist study of narrative plots' (Macey, 2001: 263) are rare, especially in business history. In organization studies, structural research-_designs are more common (e.g. Islam, 2009; Thomas, Wilson and Leeds, 2013) bbutut by no means dominant. Structuralists are interested in objective and value-free structural analysis of texts based on an assumption of universal narratological principles. Structuralist approaches include a variety of semantic and narratological methods, with (French) structuralism, formalism, and (critical) discourse analysis being the most prevalent. As this Handbook includes specific chapters on narrative methoda (Rantakari and Vaara,2016 this volume) and discourse theory (Heracleous, 2016this volume) we focus here on the few exemplary historical studies that use structuralist and formalist techniques, and especially on the opportunities such approaches might provide.

There are a few historical studies using critical discourse analysis (e.g. Mueller et al. 2013; Thomas, Wilson and Leeds 2013), typically challenging and problematizing power structures and clashes of ideology (e.g. Cakmakci and $\mathrm{Oba}_{\mathbf{4}} 2007$; Vaara ${ }_{2}$ 2002). Yet process
Muotoiltu: Taso 1, Riviväli: Kaksois

Muotoiltu: Väli Ennen: 0 pt, Riviväli: Kaksois

Muotoiltu: Tarkista oikeinkirjoitus ja kielioppi

Muotoiltu: Riviväli: Kaksois

Muotoiltu: Tarkista oikeinkirjoitus ja kielioppi

Muotoiltu: Tarkista oikeinkirjoitus ja kielioppi

Muotoiltu: Tarkista oikeinkirjoitus ja kielioppi

Muotoiltu: Tarkista oikeinkirjoitus ja kielioppi 
studies are rare. One example is the work by Moerman, van der Laan and Campbell (2014), who analyzed the change in the narrative framing of asbestos based on annual reports, identifying several distinct phases during which the meaning of asbestos turned from positive to negative. Formalist and structuralist methods differ from discourse analysis in their search for the universal semantics of texts. Todorov, Propp, Greimas, and Levi-Strauss - the most influential figures in the formalist study of literature - argued for the "'-"existence of universal grammar of narrative which generates the individual stories'stories'"- (Macey, 2001: 382). Although formalist methods were developed originally to characterize literature and other art forms (Dundes, 1997), they can also be used to arrange historical material and to question historical accounts by 'milling' materials through the formal processes designed by the above mentioned theoreticians.

While structuralist methods and historical studies have been at odds for a long time, the more recent literature provides some examples of the opportunities and constraints of formalist analyses. Lamberg and Pajunen, (2005) for instance draw on Propp's (1928/2000) folktale schema as "'-a rich resource in explaining and understanding the underlying structure in the process of organizational decline and turnarounds' turnarounds'”-(p. 972). On the one hand the authors use Propp's model as an effective tool to find a deep structure in the historical process they studied; at the same time, they also show that the popular turnaround literature has the same basic structure of narrative as Propp's folktale model. Similarly, Monin and Monin (2005) found a folktale structure in a popular management book. While the above examples assume a shared deep-level structure in all texts presented in narrative format, another methodologically interesting 
structuralist approach is to identify formal semantic structures from specific historical texts in contrast to historical narratives that researchers have created. Reveley's (2010) formal analysis of Australian entrepreneur Jules Joubert's autobiography is a good example.

Overall, while structuralist analyses remain marginal compared to other approaches, the formal analytical techniques and corresponding theoretical logics make it possible to use materials unsuitable for causalist or (con)sequentalist analysis. Moreover, the increasing digitization of historical material allows automated coding of texts (Malec, 2010), which might further motivate the use of structuralist approaches to historical analysis.

\section{-(Con)sequentialist approaches}

(Con)sequentialist approaches combine a realist ontology with an interpretative methodology. They originated in the first wave of scientific historical research in the $19^{\text {th }}$ century and have remained prevalent, especially among business historians - albeit in an implicit rather than explicit fashion (De Jong et al., 2015; Kipping, Wadhwani and Bucheli 2014). We refer to these approaches as (con)sequentialist drawing on Stinchcombe (2005), who placed historical research on an equal footing with quantitative, ethnographic and experimental methods for 'addressing causal questions in social science', with the former particularly apt at studying 'sequences of conditions, actions, and effects that have happened in natural settings' (p. 5) and at achieving a 'penetration of the details of processes and sequences' (p. 230; emphasis added). He himself was an early proponent of a historical perspective in studying organizations with work on foundation conditions (Stinchcombe, 
1965) that came to serve as an inspiration for a much wider literature today referring to 'imprinting' (Marquis and Tilcsik, 2013; Simsek, Fox, and Heavey, 2015).

While these studies give a place to history as an integral part of their theoretical framing (Kipping and Üsdiken, 2014) they often rely on secondary literature and take a stylized view of the past and the conditions imprinting different types of organizations rather than examining specific organizations and the processes that took place (but seeff. Johnson 2007's study of the origins of the Paris Opera). In these studies, one of the potential problems is that the past is seen from the present and attributed a high level of determinism in shaping current behavior. This is even more visible in studies of 'path dependence', where individual or organizational choices are seen to be increasingly reduced or eventually nullified by prior choices (Sydow, Schreyögg, and Koch, 2009).

The tendency to focus in particular on 'effects' and the urge to establish causality between prevailing conditions and these effects - rather than look at the actions and processes leading to these effects - can be illustrated with the large body of work on the emergence of the so-called multidivisional organization or M-form, widely seen as the most important organizational innovation of the $20^{\text {th }}$ century (see Kipping and Westerhuis 2012). The first to describe this decentralized organizational structure and its functioning, based on a multiyear observation within General Motors (GM), was Drucker (1946). A more systematic analysis was conducted by Chandler (1962) based on a historical and comparative study of four pioneering firms: GM, DuPont, Standard Oil of New Jersey and Sears Roebuck. Chandler looked in detail at the conditions and actions that led these companies to introduce the M- 
form in the $1920 \mathrm{~s}$ - a process study that ultimately prompted its author to suggest that this organizational innovation was the most efficient response to a series of exogenous and endogenous challenges.

Chandler's study inspired a wide range of follow-on research reaching beyond explicitly processual or historical approaches. Thus, early contingency theorists latched onto this work (see Üsdiken and Kipping 2014: 36) and-Oliver Williamson (1971) developed a testable M-form hypothesis, which dominated much of the subsequent literature on this topic. There were also more descriptive studies tracing the subsequent diffusion of the Mform in the United States and elsewhere (e.g. Whittington and Mayer 2000; Binda 2013). By contrast, only a few tried to replicate the original process-type studies. Freeland (1996, 2001) conducted in-depth archival research to examine the emergence and transformation of the M-form at General Motors, and used neo-institutional theory to derive broader insights regarding the shifting balance of power between middle and upper management and its consequences for the organizational structure. A recent archive-based study analyzed the introduction of the M-form in banking organizations (Kipping and Westerhuis ${ }_{2}$ $2012 ; 2015)$, looking at the role of internal actors as well as external consultants in a process conceptualized based on Pettigrew's (1985) earlier work on the history of the British company Imperial Chemical Industries (ICI). Pettigrew's (1985) study also used archival material combined with retrospective interviews, and this subsequently prompted him to advocate a more extensive use of history in studying organizational change (Pettigrew, Woodman and Cameron ${ }_{2}$ 2001). 


\section{Causalist approaches}

On the realist side, in addition to the (con)sequentalist tradition there is what we call the causalist perspective. The formal analytical techniques used here tend to originate in the models created by historical sociologists such as Ragin (2000) and Mahoney (e.g. Mahoney and Rueschemeyer ${ }_{4} 2003$ ), including process tracing $\left(\right.$ Mahoney $\left._{4} 2000\right)$, set analyses (Zimmermann ${ }_{4}$ 20014), event structure analysis and other methods based on the formalization of the research process (Mahoney, 2004). The use of these techniques in business history is still in a nascent phase although there are general calls for more formalization ( $\underline{\mathrm{d} D e}$ Jong $\not$ Higgins and van Driel et al., 2015). Some studies already exist, including in particular Pajunen's (2004) dissertation and subsequent journal publications (Pajunen, 2005; 2008). In these studies, Pajunen used event structure analysis and other qualitative comparative analysis (QCA) techniques to study turnaround processes in Finnish forest industry firms. These studies were among the first attempts to integrate history, process perspectives, and formal methodological techniques borrowed from historical and comparative sociology; and thus provide an example of how and why formal analytical methods might work in the context of historical process studies.

While the less formal methods help uncover historical 'truths' or anomalies and develop new, innovative theories, the formal methods of causalists allow scholars to identify patterns that are a/typical across a variety of cases and build more precise theoretical models. For process studies, causalist historical approaches potentially offer many benefits. First, the basic character of these methods is relatively close to realist case studies as conducted and reported in management journals. However, causalist approaches
Muotoiltu: Taso 1, Riviväli: Kaksois

Muotoiltu: Väli Ennen: 0 pt, Riviväli: Kaksois

Muotoiltu: Tarkista oikeinkirjoitus ja kielioppi

Muotoiltu: Tarkista oikeinkirjoitus ja kielioppi

Muotoiltu: Tarkista oikeinkirjoitus ja kielioppi

Muotoiltu: Tarkista oikeinkirjoitus ja kielioppi

Muotoiltu: Tarkista oikeinkirjoitus ja kielioppi

Muotoiltu: Riviväli: Kaksois 
strengthen the basic case study methods by allowing increased transparency in terms of how sources are used and reported, providing more complete and more authentic sources, and knowledge of the whole life cycle of the particular processes in focus. Second, causalist methods make systematic comparisons across cases possible (e.g.; Pajunen, 2004). Thise use of historical source material combined with process tracing techniques, fuzzy set analyses, and other qualitative comparative methods seems of particular value and warrants further consideration.

\section{Why study organizational processes historically? Worlds of possibilities}

As shown in the previous section, there is a small corpus of research located at the intersection of process organization studies and history, and it counts some prominent management scholars as authors and advocates. However, these studies have ultimately remained marginal. More can and should be done. Taking a historical approach to studying organizational processes, we would argue, offers a number of possibilities, which are more difficult, if not impossible to achieve through other approaches. In particular, historical research allows scholars to:

(i) Examine processes located in the past by definition, such as imprinting or field creating events;

(ii) Understand the relationship between processes and their outcomes by studying whole processes with a beginning and an end;

Muotoiltu: Sisennys:Vasen: $0 \mathrm{~cm}$ Väli Ennen: 0 pt, Lisää välilyönti samaa tyyliä olevien kappaleiden väliin, Riviväli: Kaksois 
(iii) Identify other outcomes that were possible at the time and examine why they did not materialize and, in a kind of counterfactual analysis, examine what their consequences might have been if they had materialized.

\footnotetext{
(a)

We now briefly examine these alternatives, including their advantages and potential pitfalls.4

\section{Focusing on past processes}

The first and fairly obvious advantage of a historical approach derives from its ability to study processes located in the past by definition, such as imprinting, field creating events, or path dependencies - i.e., in research where history probably has its most natural place.

These studies belong to what Kipping and Üsdiken (2014) have referred to as 'history in theory', where the past is a constitutive element of the theoretical model itself. A good

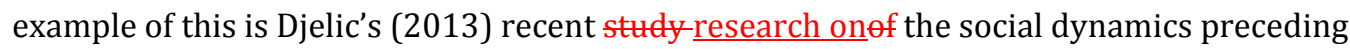
the legitimation of the concept and institutional form of limited liability. The analysis takes place in a context where limited liability was not (yet) taken for granted, but was a contested concept, which enables in depth examination of the debates at the time about the role of corporations in society and identification of the rationale for the eventual introduction of limited liability. Another example is Marquis' (2003), study of the longetivity of business community networks in the United States, where he demonstrates the strong influence of historical conditions on network dynamics even though major technological changes could potentially allow different and more efficient structures.
}

Muotoiltu: Riviväli: Kaksois

Muotoiltu: Taso 1, Riviväli: Kaksois

Muotoiltu: Riviväli: Kaksois

Muotoiltu: Taso 1, Riviväli: Kaksois

Muotoiltu: Väli Ennen: 0 pt, Riviväli: Kaksois

Muotoiltu: Tarkista oikeinkirjoitus ja kielioppi

Muotoiltu: Riviväli: Kaksois 
Studying such processes has problems of its own, owing to the difficulty of obtaining data that are akin to observations. Historical data tend to be less comprehensive and may only reflect the parts of the process that have been documented in writing, usually by certain actors for certain purposes. This is why, whenever possible, researchers have looked at processes that took place in the recent past often relying on retrospective interviews, which however have their own limitations due to selective memory (Golden, 1992). For those that did take place in a more distant past, it is important to properly contextualize them and avoid imposing concepts from the present, as was done, for example, in the above mentioneda study on the origins of the Paris Opera where King Louis XIV is characterized rather incongruously as a powerful 'stakeholder' (Johnson 2007). The historical literature has developed methods to address these biases in the available data that we will discuss below, making it possible to examine formative events that are located in a more distant past, where interviews are no longer an option.

\section{Learning from complete processes with known outcomes}

The second advantage of historical studies in comparison with contemporary studies of organizational processes is that a historical approach allows the examination of complete processes from their origins to their (final) outcomes. This is especially important for research that tries to make claims about the 'quality' of decisions and organizational actions, i.e. assessing whether or not the processes achieved the intended outcomes, or, more broadly, about the underlying causal structures of processes in terms of how they are unfolding and lead to certain outcomes, intended or not (e.g. Mintzberg and Waters, 198Kipping and Cailluet, 20107). 
It is also helpful for cases where changes are incremental, which helps explain why they were difficult to detect for actors at the time, while the outcome is only clear with hindsight. This is a possibility not always considered in current process organization studies, because it requires both a long-term perspective and the benefit of hindsight. One example is

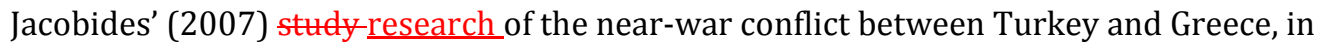
which he elaborates the process dynamics between equally possible outcomes during the political crisis. Another example, also from military history, is Stewart's (1959) pioneering study of the micro-history of one day in the 1863 Gettysburg battle. This study offers a detailed, minute-by-minute account of a process in which different outcomes were likely along the process. The author ultimately concludes that the outcome was not determined by its imprinting conditions but by the active agency of relevant actors.

The advantages of this focus on past processes become evident when contrasting them with the predominant approach of research on contemporary processes(e.g. Yin 2013). Since the latter are ongoing and unfinished, they are subject to what Rosenzweig (2007) has dubbed the 'halo effect', i.e. making conclusions based on evidence drawn from a particular moment in time, which subsequent developments reveal as biased or inaccurate. A good example for these problems is Siggelkow's (2001) case study about Liz Claiborne's apparent strategic and organizational turnaround after a period of decline. Two or three years after the completion of the original research the results would have been totally different because the company's performance deteriorated rapidly during this period. This reveals 
the original conclusions to be questionable, opening the case to alternative interpretations (f(f-Graebner, Martin ${ }_{\bar{i}}$ and Roundy, 2012).

These potential pitfalls are being addressed in some process research by tracking strategic change processes over longer periods, generally using a combination of published sources and interviews (e.g. Mintzberg ${ }_{2} 20078$ ) or by revisiting earlier research sites at more or less frequent intervals - a procedure sometimes built into the original research design (e.g. Clark and Soulsby ${ }_{2}$ 2007). Using historical cases addresses these lingering issues in a more comprehensive way. Such historical process studies allow the identification of causal mechanisms in a way that resembles Sawyer's (2004) idea of tracing a process back to the original imprint conditions. One could even argue that by selecting past research contexts with reduced or somewhat controlled variation, these historical cases can work like quasiexperiments - and particularly so if the range of variation across carefully selected comparative cases allows causal inferences, for instance about the influence of certain contextual factors on process outcomes (e.g. Haveman, Habinek and GoodmanHaveman et al., 2012).

At the same time, it is important to note that a historical approach to process organization studies is not totally devoid of periodization problems: When does historical causality end??ㅡ, i.e. when can the past no longer be made responsible for subsequent outcomes or of potential biases, often inherent in the historical sources themselves? Historical methodology has developed tools to address these issues that we discuss later. 


\section{Identifying alternative process outcomes}

Relatedly, studying the history of whole and complete processes allows researchers to understand which elements were crucial to achieve that particular outcome rather than other possible outcomes, some of which, at the outset might have seemed more plausible. In an in-depth archive-based case study, for instance, Kipping (19920027) has shown how the establishment of the European Coal and Steel Community in the 1950s was the unlikely result of a stalemate between various other options, including a state-backed European steel cartel, and engineered in part by the French planning commissioner Jean Monnet, who managed to leverage the resistance of the French car and machine tool industries against such a cartel and also won the ideological debate by contrasting American-style competitive markets with the cartelized and stagnant European economy of the inter-war period.

Similarly, in the late 1960 s the Canadian aluminum producer Alcan succeeded against all odds in building a new smelter in the UK, even though the government originally only wanted to support the expansion of the two domestic producers (Kipping and Cailluet 2010). Identifying such cases where the outcome is surprising is actually a good approach to sampling.

One could take these rich case studies with alternative outcomes further, and pursue a counterfactual analysis in terms of what might have happened had the process led to a different outcome. This approach has been promoted, for instance, by Ferguson (1997), who speculated what might have happened had the UK stayed out of the First World War or had Germany won the Second. While the study of such questions is no longer grounded in empirical evidence, it may provide some inferences about the possible thought processes of 
actors at the time weighing these different alternatives (ff.e.g. Magee ${ }_{4}$ 1997). Staying more within the realm of the real options available at the time, the difficulty lies in finding all the documentary evidence necessary for a comprehensive consideration of all alternatives; and to separate postures intended for public consumption from those underpinning actual decision-making and coalition building. While lacking the benefit of hindsight in terms of the outcome, process studies based on observations can identify and make visible the competing positions taken by various protagonists (e.g. Kaplan 2008). Historians, by contrast often write the history of the winners, which is partially a function of the latter determining what evidence is preserved. In these cases, retrospective interviews do not provide much help either, because those who might have supported alternative solutions will perhaps 'remember' having supported the winning outcome.

In sum, a historical perspective has much to offer to the study of organizational processes and can redress some of the shortcomings and biases prevalent in research focusing purely on the present or the very recent past. However, studying the past is made difficult by the availability and nature of documentary evidence and requires deliberate research strategies and a careful, systematic analysis of the historical sources, as we see next.

\section{How to do historical process organization studies? Research strategies}

While the reasons for the lack of interest in process organization studies among business historians are mainly related to the predominant research questions being asked, the
Muotoiltu: Tarkista oikeinkirjoitus ja

Muotoiltu: Tarkista oikeinkirjoitus ja kielioppi 
scarcity of historical studies among process organization scholars has its roots partly in their training. They are often more familiar with other methodologies - in particular interviews and ethnography, which also have the advantage of being widely accepted as legitimate within the community of management scholars. Most methodological handbooks in management and organization studies indeed offer limited guidance on historical research and also sometimes represent it in simplistic ways. Take for instance the following dichotomy presented by Murmann (2013: 5; emphasis added): 'The historian tries to read every document that can help piece together the most accurate presentation of what really happened. The social scientist strives to obtain representative samples and create numerical representations of the phenomenon.' While many historians probably would not recognize their work in these descriptions (see above), such an image will do little to entice process organization scholars to attempt, let alone embrace a historical approach.

Overall, those who want to conduct process organization studies based on historical cases and historical data other than interviews are left with little if any help in existing handbooks. And historians, trained through an apprenticeship-like approach since the $19^{\text {th }}$ century, have only recently started to close this gap by offering some general suggestions to management scholars on how to deal with 'the silence of the archives' (Decker, 2013;

Kipping, Wadhwani and Bucheli, 2014). We attempt to offer some elements of guidance here, to help the process researcher better grasp the historical approach. 
The key difference for those wanting to study past processes using historical methods is the need to rely on historical sources. This implies the use of 'fragments' (Ginzburg, 1989) or 'relics' (Bryant, 1994) of the past in contrast to 'evidence' as defined by most other social science scholars. Historical sources are not constructed, controlled or manipulated by the researcher. Instead, they 'are, for the most of the part, natural or authentic elements of past social worlds [...] from potsherds and pollen deposits to trash heaps and bureaucratic inventories' (Bryant, 1994: 8). As such, they 'represent either the meaningful creations or by-products of social activity [...] as residual "traces" or "objectifications" of past human actions and existential conditions' and 'bring us into rather immediate or direct contact with our subjects, "their worlds as experienced"' (ibid.). This means they tend to be highly authentic, yet seldom fully comprehensive (see also Lipartito 2014).

\footnotetext{
(
}

Professional historians have dealt with this by critically scrutinizing each relic of past organizational activity at the moment they are read in order to determine their reliability (Grigg, 1991). No information is treated as a trustworthy sign of the past before its origin, the information it contains, and its relation to other information is scrutinized (e.g. Howell and Prevenier 2001). But trustworthiness in itself is not sufficient: As one of the founders of the micro-historical genre, Carlo Ginzburg (1989: 123), has stated, 'though reality may seem to be opaque, there are privileged zones - signs, clues - which allow us to penetrate it'. Thus, historians typically look at a variety of sources to find 'clues', on which to build their reasoning and verbalization of the processes studied. This sounds easier than it is. High authenticity means that sources do not cover issues systematically: While the relevant 'signs'_ and 'clues' might be abundant in some historical sources, they are sparse or entirely
Muotoiltu: Väli Ennen: 0 pt, Riviväli: 
absent in others. Moreover, these sources do not have a narrative structure that would generate easily usable insights or that could be manipulated by 'asking the right questions'. Consequently, working with historical material requires the researcher to embed the historical relics found in their historical context; compare the documents with other sources carrying the same or similar information; and engage in logico-theoretical thinking processes, where the researcher actively works with different historical interpretations and counterfactual reasoning (Bloch, 195392; Kuzminski, 1979). Below, we briefly discuss two of the most pertinent methods used by historians in this respect.

\section{The core of historical methodology: Triangulation and hermeneutics}

In addition to source criticism, historians have developed other tools to increase the validity of their findings (Howell and Prevenier, 2001). These include two methods that, in their essence, should already be familiar to most management scholars: triangulation, to check and confirm (or question) the findings obtained from one source; and hermeneutics to place and interpret sources in their context (see also Kipping, Wadhwani and Bucheli 2014).

Triangulation can take many forms, including the independent examination of the same sources by different researchers, who then compare their findings, the use of different theoretical or conceptual lenses to the same object of study, or the application of mixed (quantitative and qualitative) methods. More commonly, it refers to the use of some combination of different observations, say interviews and documentary evidence. For most historians it would simply mean obtaining and comparing various texts covering the same 
event, or, if such texts are not available, the recourse to oral history and artifacts. What should be noted is the tendency of historians to put most faith in written primary sources, whereas management scholars, in a similar situation, would probably privilege interviews despite the pitfalls of reflective and biased recollection $\left(\right.$ Golden $_{2}$ 1992).

Two illustrative examples of the use of triangulation can be drawn from our own work. Examining the pathways of organizational change in the UK management consulting industry, Kipping and Kirkpatrick (2013) used multiple triangulation by examining quantitative and qualitative sources from the trade association archives combined with material from consulting firms and industry observers as well as secondary sources and selected retrospective interviews. Moreover, they interpreted part of the material independently and applied two theoretical lenses, namely the sociology of professions and neo-institutional theory. This approach enabled them to study change processes over half a century and propose a novel account of their underlying drivers. Similarly, examining industry-level changes among major Finnish retailers, Lamberg and Tikkanen (2006) built their study on a triangulation among a wide variety of different published and unpublished sources as well as interviews, which not only increased the validity of their findings but also helped them uncover the influence of broader technological and societal changes on decision-making at the firm level - ultimately leading to a conceptualization involving cognitive and path-dependent factors. Quite tellingly, when reconstructing the criteria behind these strategic decisions they placed significant trust in the confidential information obtained from the various company archives. 
Hermeneutics moves beyond comparing and combining sources and/or methods to examine the historical context. For historians this generally involves relating each document to other primary sources from the same time period in an iterative process. This helps to better understand the opinions and intentions of the various authors (Howell and Prevenier 2001) or, as some have put it, to reconstruct the 'voice' of that particular document (Decker 2013). Iteration occurs through re-reading and re-interpreting documents in light of newly discovered documents until interpretations remain stable even if new documents are added to the context - a process generally referred to as 'hermeneutic circle' and facilitated by the use of heterogeneous sources. While the secondary literature can serve as a starting point for this process, the researcher needs to be prepared to question and possibly reject extant interpretations in light of newly found primary sources, which might also shed new light on known documents.

A good example, where management scholars have used this approach, albeit without explicitly characterizing it as such, is the study by Munir and Phillips (2005) on the process of transforming photography into an everyday activity from its highly specialized, almost professional origins, by examining what they refer to as 'the birth of the Kodak moment'. In trying to identify the strategies that the company used to achieve this goal, they rely on primary documents from its archives but stress that these texts were 'not meaningful individually' and only became meaningful by applying a method that 'links texts to discourses and locates both within a particular social and historical context'. 
While the application of source criticism, triangulation and hermeneutics allows scholars to draw reliable and valid results from historical sources, this still leaves open the question of how to generalize from the insights gained - an area where the gap between the objectives of historians and management scholars seems rather wide, but might not be quite as unbridgeable as it looks.

\section{Going beyond the 'good story': Validation and theorization}

Thus, validity for historians is first and foremost achieved through the process of identifying and critically analyzing (primary) sources and is confirmed through triangulation and the use of the hermeneutic circle. But the process does not stop with what could be considered internal validity. Not unlike for other social sciences, there is also some external validation. As Morck and Yeung (2011: 54) succinctly note, 'To sustain credibility, a good historical narrative must connect the "dots" of all relevant historical events with causal links'. But this causality, as they also note (ibid, $)$, is less constraining than in neoclassical economics and, we would add, in the vast majority of management scholarship, since 'history is more amenable to the concept of free will' - even if historians also recognize the influence of impersonal forces in addition to individual decisions.

This

This leaves, however, the already noted issue of how to learn from historical cases, especially if these are single cases (March, Sproull and Tamuz, 1991). In terms of generating theoretical insights, a historical research strategy can be problematic. The cause-effect relationships identified tend to be complex, reflecting the 'reality' of organizational processes. Thus, when business historians explain failure they typically find from five to ten
Muotoiltu: Taso 1, Riviväli: Kaksois

Muotoiltu: Väli Ennen: 0 pt, Riviväli: Kaksois

Muotoiltu: Riviväli: Kaksois 
explanations for the outcome of the process (e.g. Jones 2002). They prefer, it seems, to reproduce and stress the complexity inherent in these cases, making it difficult to construct the crisp theoretical arguments that are usually necessary for publishing in organization and management journals. By contrast, when management scholars explain historical processes they usually find a single theoretical explanation. Thus, cognitive myopia in the Polaroid case (Tripsas and Gavetti, 2000) or), the complexity of Liz Claiborne's business architecture (Siggelkow ${ }_{\llcorner}$2001); or middle management inertia in the Kodak case (Lucas and Goh 2009) are respectively used respectively as the theoretical explanation, around which these particular cases of decline and failure have been narrated.

This does not mean that historians necessarily eschew theory and theoretical reasoning completely as has been noted by David, Sine and Haveman (2013: 361) who point out that 'historians begin with some theory, which guides them in their selection of evidence to scrutinize. They then move between their reading of the evidence and their understanding of theory, updating theory, and updating their search for evidence to investigate new ideas as they arise.' Theoretical pre-understanding, this suggests, is essential for historical researchers to create any meaningful interpretation of the historical 'relics' they find in the archives.

Another way to understand the way results emerge is to see the work of the historian as continuous theorizing (Murphey ${ }_{2} 1973$ ), i.e., in some sense as a comparative method in which the comparative judgment occurs between the theoretical knowledge and the historical interpretation (von Leyden, 1984; Walker, 1980). As the archival sources lack a 
coherent structure and/or narrative form, each piece of information must be woven into a process model in which information and events have links over time and in time (Griffin ${ }_{2}$ 1993). It should be noted though that this kind of theorizing happens largely independently of the literature that motivates the researcher to go to the archive. By contrast in the other social sciences, theoretical motivations are more explicit. For the theorizing process to make sense for both business historians and management scholars it has to be highly iterative with the simultaneous reading of theories and archival research stimulating new ways to read the literature and the archival sources (Shanahan 1989).

\section{Conclusion}

Muotoiltu: Taso 1, Riviväli: Kaksois

We started by examining the reasons why process organization studies and historical research (as historians understand it) have remained largely isolated streams of research. One major reason for the lack of cross-fertilization is that, on average, management scholars have only a very vague understanding of the requirements and advantages of the historical method. This is due to the lack of proper methods books, articles, and PhD courses on these methods. The situation has improved somewhat after the first calls for more history in the 1990s by the likes of Zald and Kieser (see Üsdiken and Kipping 2014), a growing number of methodological articles (e.g. Decker 2013; Decker et al., 2015; Kipping Wadhwani and Bucheli, et al.,2014;) and the establishment of specialized journals, in particular Management \& Organizational History. Yet, despite this progress, process scholars may have difficulty in identifying historical methods as a distinctive and valuable 
approach for studying organizational processes. On the other hand, historians - even business historians - do not recognize the field-specific theoretical and conceptual issues that make process studies distinct from other forms of organization and management studies.

Our aim has been to highlight (a) the versatile nature, in an onto-epistemological and methodological sense, of historical studies; and (b) the opportunities a proper historical approach could offer for process scholars. First, echoing more general tendencies in the social sciences, historians differ onto-epistemologically and in terms of the methods they use. Although the vast majority of historians do research from a 'naturalistic' perspective, there are also camps that favor narrative analysis, formal structural analyses of texts, comparative methods, and process tracing techniques. As we have stressed, however, the use of historical sources requires specific types of skills and a very different type of philosophical stance towards reasoning compared to other social sciences. Especially, when making interpretations of the motives and logics of past actors, historians engage in an active reasoning process that results in historical descriptions and conclusions. The researcher's role is elemental not only as an observer but more importantly as a mechanism kind of mediator between the relics of the past and contemporary scholarly discussions.

Second, we have offered reasons for using a historical approach and we have suggested ways of conducting such research. A historical approach is especially valuable when studying processes located in the past 'by definition' fsuch as imprinting or field creating events and f); when studying relationships between processes and their outcomes. It also 
allows; and when to considering other outcomes that were possible at the time, examining why they did not materialize and what the consequences might have been if they had. While these reasons seem intuitively clear they have not catalyzed large volumes of research on the scale of other well-defined approaches to qualitative research. We argue that the recent historiographical method literature even in the leading management journals (e.g. Kipping and Üsdiken, 2014; Maclean, Harvey and Clegg 2016; Rowlinson, Hassard and Decker et al., 2014; Maclean, Harvey and Clegg 2015; Vaara and Lamberg, 20152016) may be not enough to make historical processes more accessible to process researchers. We have therefore highlighted the importance of source criticism, triangulation, hermeneutic treatment and constant iterative theorizing, and hermeneutic treatment of materials in the making of historical analyses of processes. Perhaps more importantly, our text hopefully functions as a reminder of the innovative historical research that has already been conducted in the field of process organization studies and offers some alternative ways forward.

References (to be completed)

\section{Binda 2013}

Bloch, Marc- (195392): The historian's craft. New York:- KnopfManchester University Press.

Bryant, Joseph= M. (1994): 'Evidence and explanation in history and sociology: $\underline{\text { Ceritical }}$ reflections on Goldthorpe's critique of historical sociology' British Journal of Sociology, 45(1):-:3-19. 
Burgelman, Richard A. "Bridging history and reductionism: A key role for longitudinal qualitative research." Journal of International Business Studies 42 (2011): 591-601.

\section{Burrell, Gibson, and Morgan, Gareth (-1979)_-Sociological paradigms and organisational} analysis (Vol. 248). London:-Heinemann,: London.

CakmakclCakmakci, U., Ufuk and B. Oba, Beyza- (2007) '"-The role of employer unions in hegemonic struggle, interest representation and promotion of managerial perspectives in Turkey' "Business History 4 49(5): 695-716.

Carter, Chris and McKinlay, Alan (2013) 'Cultures of strategy: Remaking the BBC, 1968-

2003', Business History, 55(7): 1228-46.

\section{Carter McKinlay 2013}

Chandler, Alfred D. (-1962) Strategy and structure: Chapters in the history of the industrial

$$
\text { enterprise. Cambridge, MA: MIT Press. }
$$

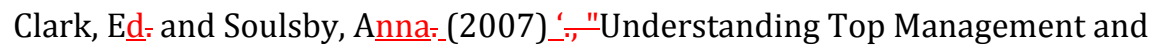

Organizational Change Through Demographic and Processual Analysis,_, Journal of

$$
\text { Management Studies_-44-(6):-pp-932-954. }
$$

Clark, Peter; and Michael-Rowlinson. Michael (2004): '-"The treatment of history in

organisation studies: towards an “-'historic turn"'-?'_- Business History _-46(3):_331-52.

Collingwood, Robin :G. (1946)_The idea of history. New-Oxford: ClarendonYork: Oxford

University Press, $1956 \underline{1946}$.

Daniel M. G. Raff 2000, Superstores and the Evolution of Firm Capabilities in American

Bookselling, Strategic Management Journal Vol. 21, No.10/11, Special Issue: The

Evolution of Firm Capabilities (Oct.-Nov., 2000), pp. 1043-1059 
David, Robert: J., Sine, Wesley D., W. D., \&-Haveman, Heather A.H. A. (2013): 'Seizing

Opportunity in Emerging Fields: How Institutional Entrepreneurs Legitimated the

Professional Form of Management Consulting', Organization Science, 24(2): 356-377.

de Jong, Abe, Higgins, David M. and van Driel, Hugo (2015) 'Towards a new business

history?', Business History, 57(1): 5-29.

Decker, Stephanie (2013) 'The silence of the archives: business history, post-colonialism

and archival ethnography', Management \& Organizational History, 8(2): 155-73.

Decker, Stephanie, Kipping, Matthias and Wadhwani, R. Daniel (2015) 'Decker 2013

New business histories! Plurality in business history research methods', Business History,

57(1): 30-40.

\section{Decker, Kipping, Wadwhani 2015}

Djelic, Marie-Laure $(-2013)-"$-When limited liability was (still) an Issue: mobilization and

politics of signification in 19th-century England'" Organization Studies, $34(5-6):$ :595-

621.

Drucker, Peter F.(1946) Concept of the Corporation. New York: John Day.

Dundes, Alan (1997) “"Binary opposition in myth: The Propp/Levi-Strauss debate in retrospect"”-"Western Folklore, 56(1):-39-50.

Durepos, Gabrielle- and Albert J Mills ${ }_{4 \bar{i}}$ Albert I. (2012)- "'Actor-network theory, ANTi-

history and critical organizational historiography'" Organization

Ehrhardt, 0., and E. Nowak. 2011. "The evolution of German industrial legends: The case of

Baden-Wurttemberg, 1940-2007." Business History 53(1):144-68.

Eloranta, Jari, Jari Ojala, and Heli Valtonen. 2010. "Quantitative methods in business history:

An impossible equation?" Management \& Organizational History 5(1):79-107.
Muotoiltu: Fontti: Kursivoitu

Muotoiltu: Väli Jälkeen: 0 pt, Riviväli: Kaksois

Muotoiltu: Fontti: Kursivoitu

Muotoiltu: Väli Ennen: 0 pt, Riviväli: Kaksois

Muotoiltu: Tarkista oikeinkirjoitus ja kielioppi, Ei Korosta

Muotoiltu: Väli Jälkeen: 0 pt

Muotoiltu: Tarkista oikeinkirjoitus ja kielioppi

Muotoiltu: Väli Ennen: 0 pt, Riviväli: Kaksois

Muotoiltu: Tarkista oikeinkirjoitus ja kielioppi

Muotoiltu: Tarkista oikeinkirjoitus ja kielioppi

Muotoiltu: Tarkista oikeinkirjoitus ja kielioppi

Muotoiltu: Tarkista oikeinkirjoitus ja kielioppi

Muotoiltu: Tarkista oikeinkirjoitus ja kielioppi

Muotoiltu: Tarkista oikeinkirjoitus ja kielioppi

Muotoiltu: Tarkista oikeinkirjoitus ja

kielioppi

Muotoiltu

Muotoiltu

Muotoiltu: Fontti: Kursivoitu

Muotoiltu

Muotoiltu

Muotoiltu

Muotoiltu

Muotoiltu

Muotoiltu

Muotoiltu

Muotoiltu

Muotoiltu

Muotoiltu

Muotoiltu

Muotoiltu

Muotoiltu

Muotoiltu

Muotoiltu

Muotoiltu

Muotoiltu 
Ericson, Mona, Melin, Leif ${ }_{\overline{\bar{i}}}$ and Popp, Andrew:(2015): “-Studying strategy as practice

through historical methods', i”. In D. Golsorkhi, L. Rouleau, D. Seidl and,\& E. Vaara

(eEds.), Cambridge Handbook of Strategy as Practice, 2ndsecond edition. Cambridge:

Muotoiltu: Fontti: Kursivoitu

Cambridge University Press, forthcoming, pp. 506-19.-

Fergusson, Niall (ed__itor) [1997_ Virtual History: Alternatives and Counterfactuals. London,

Macmillan.

Freeland, R.F. (1996). The Myth of the M-form? Governance, Consent and Organizational

Change. American Journal of Sociology 102, 483-526.

Freeland, Robert- F. (2001): The Struggle for Control of the Modern Corporation:

Organizational Change at General Motors, 1924-1970. CambridgeNew York: Cambridge

University Press.-

Ginzburg, Carlo- (1989) Clues, myths, and the historical method. Baltimore MD: Johns

Hopkins University Press., 1989.

Golden, Brian- R. (1992): 'The past is the present - or is it? The use of retrospective accounts as indicators of past strategy' ${ }_{2}$ Academy of Management Journal, 35(4):- 848-60.

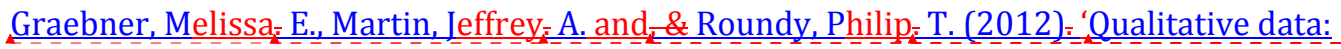

Cooking without a recipe', - Strategic Organization, $10 .(3):-276-284$.

Griffin, Larry= J. (1993): 'Narrative, event-structure analysis, and causal interpretation in historical sociology': American Journal of Sociology, 98(5):-1094-1133.

Grigg, Susan- (1991): 'Archival practice and the foundations of historical method', The Journal of American History, 78(1):- 228-239. 
Hansen, Per H.,(2007) 'Organizational Culture and Organizational Change: The

Transformation of Savings Banks in Denmark, 1965-1990', Enterprise \& Society, 8(4): 920-53.

Hansen, Per- H. (2012)_-"'Business History: A Cultural and Narrative Approach'," Business History Review__-86(4):_693-717.

Haveman, Heather A., Habinek, Jacob and Goodman, Leo A. (2012) 'How Entrepreneurship Evolves: The Founders of New Magazines in America, 1741-1860', Administrative Science Quarterly, 57(4): 585-624. Haveman et al 2012

Heracleous, L. 2016. 'Discourse theory'. Sage Handbook of Process Organization Studies (eds. Tsoukas \& Langley). SAGE, London.

Howell, Martha C.:-and Prevenier, Walter -(2001): From reliable sources: An introduction to historical methods $s_{1^{-}}$Ithaca, NY: Cornell University Press.

Islam, G. 2009. "Animating leadership: Crisis and renewal of governance in 4 mythic narratives." Leadership Quarterly 20(5):828-36.

Jacobides, Michael- G. (2007)- "The inherent limits of organizational structure and the

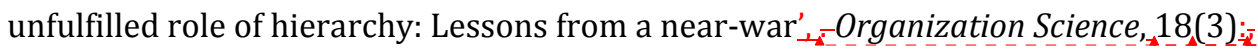
455-477.

Johnson, Victoria (2007) 'What Is Organizational Imprinting? Cultural Entrepreneurship in the Founding of the Paris Opera', American Journal of Sociology, 113(1): 97-127 Lohnson 2007

Jones, Geoffrey (2002) '-Control, Performance, and Knowledge Transfers in Large Multinationals: Unilever in the United States, 1945-1980'_" Business History Review 76(3)(fall 2002): 435-478:
Muotoiltu: Ei Korosta

Muotoiltu: Ei Korosta

Muotoiltu: Ei Korosta

Muotoiltu: Fontti: Kursivoitu

Muotoiltu: Ei Korosta

Muotoiltu: Ei Korosta

Muotoiltu: Fontti: Kursivoitu

Muotoiltu: Ei Korosta

Muotoiltu: Tarkista oikeinkirjoitus ja

kielioppi

Muotoiltu: englanti (Yhdysvallat)

Muotoiltu: englanti (Yhdysvallat)

Muotoiltu: englanti (Yhdysvallat)

Muotoiltu: englanti (Yhdysvallat)

Muotoiltu: englanti (Yhdysvallat)

Muotoiltu: englanti (Yhdysvallat)

Muotoiltu: Fontti: Ei Kursivoitu, englanti (Yhdysvallat)

Muotoiltu: englanti (Yhdysvallat)

Muotoiltu: englanti (Yhdysvallat)

Muotoiltu: Fontti: Kursivoitu

Muotoiltu: Fontti: Kursivoitu 
Long, Higgins, van Driel 2015

Kaplan, Sarah (2008) '--Framing Contests: Strategy Making Under Uncertainty'”,

Organization Science $19(5):$ 729-52.

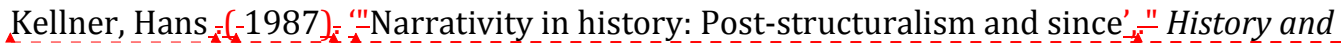
Theory 26(4):1-29.

Kipping, Matthias, (2002199) La France et les origines de l'Union européenne, 1944-1952:

Intégration économique et compétitivité international. Paris: CHEFF.

Kipping, Matthias and Cailluet, Ludovic (2010) 'Mintzberg's Emergent and Deliberate

Strategies: Tracking Alcan's Activities in Europe, 1928-2007', Business History Review,

84(1): 79-104.

7

Kipping Cailluet 2010

Kipping, Matthias, and Kirkpatrick, Ian, (2013) 'Alternative Pathways of Change in

Professional Service Firms: The Case of Management Consulting', Journal of

Management Studies, 50(5): 777-807.

Kipping, Matthias, Wadhwani, R. Daniel and Bucheli Marcelo (2014) 'Analyzing and

Interpreting Historical Sources: A Basic Methodology', in M. Bucheli and R. D.

Wadhwani (eds.),,Organizations in Time: History, Theory, Methods. Oxford: Oxford

University Press, pp. 305-329ipping, Wadhwani and Bucheli 2014.

Muotoiltu: Fontti: Kursivoitu

Muotoiltu: Ei Korosta

Kipping, Matthias and Üsdiken, Behlül (2014) 'History in Organization and Management

Theory: More than meets the eye', Academy of Management Annals, 8(1): 535-88.

Kipping, Matthias, and Westerhuis, Gerarda (2012), 'Strategy, Ideology and Structure: The

political processes of introducing the M-form in two Dutch banks', in Steven J. Kahl, 
Brian S. Silverman, and Michael A. Cusumano (eds.), History and Strategy. Bingley:

Emerald, pp. 187-237 (= Advances in Strategic Management, 29).

and Westerhuis 2012

Kipping and Westerhuis 2015

Kuzminski, Adrian (-1979L_-Defending Historical Realism',-History and Theory $\div$-8(3): 31649.316-349.

Lamberg, Juha-Antti, and Kalle Pajunen_(-2005)' "Beyond the metaphor: The morphology of organizational decline and turnaround'"Human Relations $s_{-4}^{-58(8): 947-80 .}$

Lamberg, Juha--Antti- and \&-Tikkanen, Henrikki- (2006): 'Changing sources of competitive advantage: cognition and path dependence in the Finnish retail industry 1945-1995', -Industrial and Corporate Change, $-15,(5):-811-846$.

Langley, Ann, (1999): 'Strategies for theorizing from process data',-Academy of

Management Rreview, 24,(4):- 691-710.

Lipartito, Kenneth (-2014) 'Historical Sources and Data', in M. Bucheli and R. D. Wadhwani

(eds.), Organizations in Time: History, Theory, Methods. Oxford: Oxford University

Press, pp. 284-304.

Lucas, Henry C, and Jie Mein Goh. 2009. "Disruptive technology: How Kodak missed the digital photography revolution." The Journal of Strategic Information Systems $18(1): 46-55$

Macey, David (2001) Dictionary of Critical Theory - London: Penguin Books, London. Maclean, Mairi, Charles-Harvey, Charles and Clegg, Stewart_legg. (20165)."

'Conceptualizing Historical Organization Studies', 'Academy of Management Review forthcoming

\begin{tabular}{|c|c|}
\hline Muotoiltu & $\ldots[20]$ \\
\hline Muotoiltu & $\ldots[21]$ \\
\hline Muotoiltu & $\ldots[22]$ \\
\hline Muotoiltu & $\ldots[23]$ \\
\hline Muotoiltu & $\ldots[24]$ \\
\hline Muotoiltu & $\ldots[25]$ \\
\hline Muotoiltu & $\ldots[26]$ \\
\hline Muotoiltu & $\ldots[27]$ \\
\hline Muotoiltu & $\ldots[28]$ \\
\hline Muotoiltu & $\ldots[29]$ \\
\hline Muotoiltu & $\ldots[30]$ \\
\hline Muotoiltu & $\ldots[31]$ \\
\hline Muotoiltu & $\ldots$ [32] \\
\hline Muotoiltu & $\ldots$ [33] \\
\hline Muotoiltu & ... [34] \\
\hline Muotoiltu & $\ldots[35]$ \\
\hline Muotoiltu & $\ldots$ [36] \\
\hline Muotoiltu & $\ldots[37]$ \\
\hline Muotoiltu & $\ldots[38]$ \\
\hline Muotoiltu & $\ldots$ [39] \\
\hline Muotoiltu & $\ldots[40]$ \\
\hline Muotoiltu & $\ldots$ [41] \\
\hline Muotoiltu & $\ldots[42]$ \\
\hline Muotoiltu & $\ldots$ [43] \\
\hline Muotoiltu & $\ldots$ [44] \\
\hline Muotoiltu & $\ldots[45]$ \\
\hline Muotoiltu & $\ldots[46]$ \\
\hline Muotoiltu & ... [47] \\
\hline Muotoiltu & $\ldots$ [48] \\
\hline Muotoiltu & $\ldots$ [49] \\
\hline Muotoiltu & $\ldots[50]$ \\
\hline Muotoiltu & $\ldots$ [51] \\
\hline Muotoiltu & $\ldots[52]$ \\
\hline Muotoiltu & ... [53] \\
\hline Muotoiltu & $\ldots[54]$ \\
\hline Muotoiltu & $\ldots[55]$ \\
\hline Muotoiltu & $\ldots[56]$ \\
\hline Muotoiltu & $\ldots$ [57] \\
\hline Muotoiltu & $\ldots[58]$ \\
\hline Muotoiltu & $\ldots$ [59] \\
\hline Muotoiltu & $\ldots[60]$ \\
\hline Muotoiltu & $\ldots[61]$ \\
\hline Muotoiltu & $\ldots[62]$ \\
\hline Muotoiltu & $\ldots[63]$ \\
\hline
\end{tabular}


Magee, Gary B. (1997)_'CCompetence or omniscience? Assessing entrepreneurship in the Victorian and Edwardian British paper industry," Business History Review 71( $(\theta 2)$ : 230-59.

Mahoney, James; and Dietrich-Rueschemeyer. Dietrich (2003). Comparative historical analysis in the social sciences. New York:- Cambridge University Press.

Mahoney, James_-2000) “"-Strategies of causal inference in small-N analysis's." Sociological Methods \& Research $-28(4): 387-424$.

Mahoney, James_(-2004)."_Comparative-Historical Methodology',"'Annual Review of Sociology $-30: 81-101$.

Malec, Scott A. (2010): “-'AutoPropp: Toward the automatic markup classification, and annotation of Russian magic tales', $1^{\text {st }}$ International AMICUS Workshop, Vienna, Austria.

March, James G., Lee S.Sproull, Lee S.- and MichalTamuz Michal (-1991): '-Learning from Samples of One or Fewer'"-, Organization Science, 2(1): 1-13.

Marquis, Christopher (-2003): "'The pressure of the past: Network imprinting in intercorporate communities' Administrative Science Quarterly $48(4): 655-89$.

Marquis, Christopher and Tilcsik, András- (2013): 'Imprinting: Toward A Multilevel Theory', -Academy of Management Annals, 7(1): 193-243, 2013

Marquis,Christopher. 2003 ."The prescure of the past: Network imprinting in

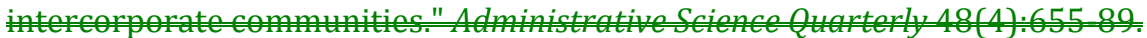

McKinlay, Alan (2013): 'Following Foucault into the archives: Celerks, careers and cartoons', -Management \& Organizational History, 2013Vol.8(, No.2): -137-154.
Muotoiltu: Tarkista oikeinkirjoitus ja kielioppi

Muotoiltu: Tarkista oikeinkirjoitus ja kielioppi

Muotoiltu: Tarkista oikeinkirjoitus ja kielioppi

Muotoiltu: Tarkista oikeinkirjoitus ja kielioppi

Muotoiltu: Tarkista oikeinkirjoitus ja kielioppi

Muotoiltu: Tarkista oikeinkirjoitus ja kielioppi

Muotoiltu: Tarkista oikeinkirjoitus ja kielioppi

Muotoiltu: Tarkista oikeinkirjoitus ja kielioppi

Muotoiltu: Tarkista oikeinkirjoitus ja kielioppi

Muotoiltu: Tarkista oikeinkirjoitus ja kielioppi

Muotoiltu: Tarkista oikeinkirjoitus ja kielioppi

Muotoiltu: Tarkista oikeinkirjoitus ja kielioppi

Muotoiltu: Tarkista oikeinkirjoitus ja kielioppi

Muotoiltu: Tarkista oikeinkirjoitus ja kielioppi

Muotoiltu: Fontti: Kursivoitu

Muotoiltu: Tarkista oikeinkirjoitus ja kielioppi

Muotoiltu: Tarkista oikeinkirjoitus ja kielioppi

Muotoiltu: Tarkista oikeinkirjoitus ja kielioppi

Muotoiltu: Tarkista oikeinkirjoitus ja kielioppi

Muotoiltu: Tarkista oikeinkirjoitus ja kielioppi

Muotoiltu: Tarkista oikeinkirjoitus ja kielioppi

Muotoiltu: Tarkista oikeinkirjoitus ja kielioppi

Muotoiltu: Tarkista oikeinkirjoitus ja kielioppi

Muotoiltu: Fontti: Kursivoitu

Muotoiltu: Tarkista oikeinkirjoitus ja kielioppi

Muotoiltu: Fontti: Kursivoitu 
McLaren, Patricia Genoe, Albert J.Mills, Albert I. and Terrance G.Weatherbee ${ }_{2}$ Terrance G. (2015)5) The Routledge Companion to Management and Organizational History. New York:-_Routledge.

Mintzberg Waters 1982

Mintzberg, Henry (-20078), Tracking strategies: Toward a general theory. Oxford: University

Press, 2007.

Moerman, Lee-, S.van der Laan, Sandra and D.Campbell, David asbestos giants: Corporate reports as (auto)biography' $975-95$.

Monin, Nanette $\bar{j}_{\bar{j}}$ and John-Monin ${ }_{\bar{L}_{\overline{\mathrm{i}}}}$ John (2005) "Hijacking the fairy tale: Genre blurring and allegorical breaching in management literature'_"Organization ${ }_{-}-12(4): 511-28$.

Morck, Randall $=$ and B.Yeung, Bernard. (2011)."_Economics, History, and Causation'_." Business History Review__-85(1):_39-63.

Mueller, Frank $=$, A.Whittle, Andrea, - Gilchrist, Alan and P.Lenney, Peter and strategy practice: An ethnomethodologically-informed discourse analysis perspective', "Business History

Munir, Kamal A. and Phillips, Nelson (2005) 'The Birth of the "Kodak Moment": Institutional Entrepreneurship and the Adoption of New Technologies', Organization Studies, 26(11): 1665-87.

Murmann, Johann- Peter (-2013):- 'The Coevolution of Industries and Important Features of Their Environments,_-Organization Science, 24(1): 58-78.

Murphey, Murray: G. (1973): Our knowledge of the historical past. Indianapolis, IN: Bobbs-

\section{Merrill.Oxford University Press, Oxford.}

Muotoiltu: Tarkista oikeinkirjoitus ja kielioppi, Ei Korosta

Muotoiltu: Tarkista oikeinkirjoitus ja kielioppi, Ei Korosta

Muotoiltu: Tarkista oikeinkirjoitus ja kielioppi, Ei Korosta

Muotoiltu: Fontti: Kursivoitu

Muotoiltu: Tarkista oikeinkirjoitus ja kielioppi, Ei Korosta

Muotoiltu: Tarkista oikeinkirjoitus ja kielioppi

Muotoiltu: Tarkista oikeinkirjoitus ja kielioppi

Muotoiltu: Tarkista oikeinkirjoitus ja kielioppi

Muotoiltu

Muotoiltu

Muotoiltu

Muotoiltu

Muotoiltu

Muotoiltu

Muotoiltu

Muotoiltu

Muotoiltu

Muotoiltu

Muotoiltu

Muotoiltu

Muotoiltu

Muotoiltu

Muotoiltu

Muotoiltu

Muotoiltu

Muotoiltu

Muotoiltu

Muotoiltu

Muotoiltu

Muotoiltu

Muotoiltu

Muotoiltu

Muotoiltu: Ei Korosta

Muotoiltu: Ei Korosta

Muotoiltu: Ei Korosta

Muotoiltu: Ei Korosta

Muotoiltu: Fontti: Kursivoitu

Muotoiltu: Ei Korosta 
Pajunen, Kalle (-2004)_Explaining by mechanisms: Aa study of organizational decline and turnaround processes', Doctoral dissertation, Tampere University of Technology,

Finland.

Pajunen, Kalle $(-20052-$ "'Comparative causal analysis in processual strategy research: Az study of causal mechanisms in organizational decline and turnarounds',"Advances in Strategic Management 2 -22: 419-61.

Pajunen, Kalle- (2008), "'The nature of organizational mechanisms'" Organization Studies 29(11): 1449-68.

Pettigrew, Andrew: M. (1985): The Awakening Giant: Continuity and Change in Imperial Chemical Industries. Oxford: Blackwell.

Pettigrew, Andrew- M., Woodman, Richard: W.and, \& Cameron, Kim. S. (2001): 'Studying Organizational Change and Development: Challenges for Future Research',-Academy of Management Journal $-44(+4):-697-713$.

Propp, Vladimir Y (1928/2000) Morphology of the folktale Austin, TX: American Folklore Society and Indiana University.

Quinn, Stephen: (2001) "'The Glorious Revolution's Effect on English Private Finance: A

Microhistory, 1680-1705'" The Journal of Economic History

Raff, Daniel M. G. (2000); 'Superstores and the Evolution of Firm Capabilities in American

Bookselling', Strategic Management Journal, Vol.21(,No.10/11): , Special Issue: The

Evolution of Firm Capabilities (Oct. - Nov, 2000), pp.1043-1059.

Ragin, Charles C. (2000), Fuzzy-set social science. Chicago, IL::- The University of Chicago

Press.

\begin{tabular}{|l|}
\hline \multicolumn{1}{|l}{ Muotoiltu: Tarkista oikeinkirjoitus ja } \\
kielioppi
\end{tabular}


Rantakari, A. and Vaara, E. (2016). 'Narratives and processuality'. Sage Handbook of Process Organization Studies (eds. Tsoukas \& Langley). SAGE, London.

Reveley, James_(-2010)_"'Using autobiographies in business history: Aa narratological analysis of Jules Joubert's Shavings and Scrapes'_" Australian Economic History Review $_{\text {L- }}$ 50(3):284-305.

Rosenzweig, Phil (2007): 'Misunderstanding the nature of company performance: the halo effect and other business delusions-', ECalifornia Management Review, $49,(4), 6-20$.

Rowlinson, M. (2004). 'Historical analysis of company documents'. In C. Cassell and G.

Symon (eds), Essential guide to qualitative methods in organizational research.

London: Sage, 301-311

$\underline{\text { Rowlinson, Michael, Hassard, John and Decker, Stephanie (2014) 'Strategies for }}$

organizational history: A dialogue between historical theory and organization theory', Academy of Management Review, 39(3): 250-74.

Sawyer, R. Keith- (2004):"-The mechanisms of emergence'"-2 Philosophy of the Social Sciences_-34(2):_260-82.

Shanahan, Murray: (1989): 'Prediction is Deduction but Explanation is Abduction', Paper presented at the IJCAI 89.

Siggelkow, Nicolaj; (2001): 'Change in the presence of fit: The rise, the fall, and the renaissance of Liz Claiborne', -Academy of Management Journal, 44.(4):-838-857.

Simsek, Zeki, Brian Curtis-Fox, Brian Curtis and Ciaran-Heavey Ciaran (-2015)=-"-“"-What's

Past Is Prologue": A Framework, Review, and Future Directions for Organizational Research on Imprinting,_"Journal of Management ${ }_{\llcorner}-41(1): 288-317$.
Muotoiltu: englanti (Yhdysvallat)

Muotoiltu: Tarkista oikeinkirjoitus ja kielioppi

Muotoiltu: Tarkista oikeinkirjoitus ja kielioppi

Muotoiltu: Tarkista oikeinkirjoitus ja kielioppi

Muotoiltu: Tarkista oikeinkirjoitus ja

kielioppi

Muotoiltu: Tarkista oikeinkirjoitus ja kielioppi

Muotoiltu: Tarkista oikeinkirjoitus ja kielioppi

Muotoiltu: Tarkista oikeinkirjoitus ja

kielioppi

Muotoiltu: Tarkista oikeinkirjoitus ja kielioppi

Muotoiltu: englanti (Yhdysvallat), Ei Korosta

Muotoiltu: englanti (Yhdysvallat), Ei

Korosta

Muotoiltu: englanti (Yhdysvallat), Ei Korosta

Muotoiltu: Fontti: Ei Kursivoitu, englanti (Yhdysvallat), Ei Korosta

Muotoiltu: Fontti: Ei Kursivoitu

Muotoiltu: englanti (Yhdysvallat), Ei

Korosta

Muotoiltu: englanti (Yhdysvallat), Ei Korosta

Muotoiltu: Fontti: Ei Kursivoitu, englanti (Yhdysvallat), Ei Korosta

Muotoiltu: englanti (Yhdysvallat), Ei

Korosta

Muotoiltu: Taso 1, Väli Ennen: 0 pt, Riviväli: Kaksois

Muotoiltu: Fontti: Kursivoitu

Muotoiltu

Muotoiltu: Ei Korosta

Muotoiltu: Ei Korosta

Muotoiltu: Fontti: Ei Kursivoitu

Muotoiltu

Muotoiltu

Muotoiltu

Muotoiltu

Muotoiltu

Muotoiltu

Muotoiltu

Muotoiltu

24]

125

26]

[127]

[129]

[130]

[131]


Sorensen, B. M. 2008. "'Behold, I am making all things new': The entrepreneur as savior in the age of creativity." Scandinavian Journal of Management 24(2):85-93.

Steinmetz, George - (1998): 'Critical realism and historical sociology. A review article', Comparative Studies in Society and History, $40,(01): 170-186$.

Stewart, RGeorge R. (1959): Pickett's Charge: A Microhistory of the Final Attack at

Gettysburg, July 3, 1863. Boston, MA: Houghton Mifflin-Company.

Stinchcombe, Arthur L. (1965) 'Social structure and organizations', in J. G. March (ed.),

Handbook of organizations. Chicago, IL: Rand McNally, pp. 142-193.

Stinchcombe 1965

Stinchcombe, Arthur- L. (2005); The Logic of Social Research. Chicago, IL: Tthe University of Chicago Press.

Stopford, John M, and Louis T Wells Jr. 1972. "Managing the MNE: Organization of the Firm and Ownership of the Subsidiaries." New York: Basic Books1972.

Sydow, Jörg, Schreyögg, Georg , and Koch, Jochen (-2009) “' 'Organizational path dependence: Opening the black box' Academy of Management Review $34(\div 4) ; 689-$ 709.

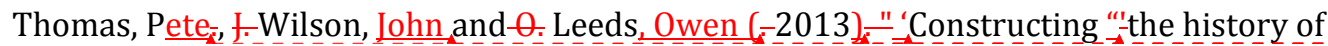
strategic management"': A critical analysis of the academic discourse', History $-55(7): 1119-42$.

Tripsas, Mary; and Giovanni Gavetti- (2000)- '-Capabilities, cognition, and inertia: Evidence from digital imaging',"Strategic Management Journal_-21(10-11):_1147-61.

Üsdiken Kipping 2014
Muotoiltu: englanti (Yhdysvallat),

Tarkista oikeinkirjoitus ja kielioppi, Ei

Korosta

Muotoiltu: englanti (Yhdysvallat)

Tarkista oikeinkirjoitus ja kielioppi, Ei

Korosta

Muotoiltu: englanti (Yhdysvallat)

Tarkista oikeinkirjoitus ja kielioppi, Ei

Korosta

Muotoiltu: englanti (Yhdysvallat),

Tarkista oikeinkirjoitus ja kielioppi, Ei

Korosta

Muotoiltu: englanti (Yhdysvallat)

Tarkista oikeinkirjoitus ja kielioppi, Ei

Korosta

\begin{tabular}{|c|c|}
\hline Muotoiltu & $\ldots[132]$ \\
\hline Muotoiltu & $\ldots[133]$ \\
\hline Muotoiltu & $\ldots[134]$ \\
\hline Muotoiltu & $\ldots[135]$ \\
\hline Muotoiltu & $\ldots[136]$ \\
\hline Muotoiltu & $\ldots[137]$ \\
\hline \multicolumn{2}{|c|}{ Muotoiltu: Ei Korosta } \\
\hline \multicolumn{2}{|c|}{ Muotoiltu: Fontti: Kursivoitu } \\
\hline Muotoiltu & $\ldots[138]$ \\
\hline Muotoiltu & $\ldots[139]$ \\
\hline Muotoiltu & $\ldots[140]$ \\
\hline Muotoiltu & $\ldots[141]$ \\
\hline Muotoiltu & $\ldots[142]$ \\
\hline Muotoiltu & $\ldots[143]$ \\
\hline Muotoiltu & $\ldots[144]$ \\
\hline Muotoiltu & $\ldots[145]$ \\
\hline Muotoiltu & $\ldots[146]$ \\
\hline Muotoiltu & $\ldots[147]$ \\
\hline Muotoiltu & $\ldots[148]$ \\
\hline Muotoiltu & $\ldots[149]$ \\
\hline Muotoiltu & $\ldots[150]$ \\
\hline Muotoiltu & $\ldots[151]$ \\
\hline Muotoiltu & $\ldots[152]$ \\
\hline Muotoiltu & $\ldots[153]$ \\
\hline Muotoiltu & $\ldots[154]$ \\
\hline Muotoiltu & $\ldots[155]$ \\
\hline Muotoiltu & $\ldots[156]$ \\
\hline Muotoiltu & $\ldots[157]$ \\
\hline Muotoiltu & $\ldots$ [158] \\
\hline Muotoiltu & $\ldots$ [159] \\
\hline Muotoiltu & $\ldots[160]$ \\
\hline
\end{tabular}


Vaara, Eero (-2002) ${ }_{-1}$ On the discursive construction of success/failure in narratives of

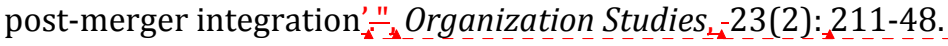

Vaara, Eero, and Juha-Antti Lamberg, Juha-Antti ( 20152016): "'Taking historical embeddedness seriously: Three historical approaches to advance strategy process and practice research', ${ }_{\perp-1}$ Academy of Management Review forthcoming:amr. 2014.0172.

Vaara, Eero, Scott Sonenshein, and David Boje. 2015. "Narratives as Sources of Stability and Change in Organizations: Approaches and Directions for Future Research." The Academy of Management Annals (just-accepted):1-71.

von Leyden, Wolfgang= (1984): 'Categories of historical understanding': History and Theory ${ }_{2}$ 23(1):: 53-77.

Walker, Lawrence=- D. (1980): 'A Note on Historical Linguistics and Marc Bloch"'s Comparative Method ${ }_{\perp=}^{\prime}$ History and Theory ${ }_{2} 19(2): \div 154-164$.

White, Hayden V. (1975)= '-Historicism, history, and the figurative imagination'="- History and Ttheory, 14(4), Beiheft 14: Essays on Historicism: : 48-67.

Whittington, Richard, Michael Mayer, and Francesco Curto. 1999. "Chandlerism in post-war Europe: strategic and structural change in France, Germany and the UK, 1950-1993." Industrial and Corporate Change 8(3):519-51.

Whittington, Richard and Mayer, -Mayer (2000), The European corporation: Strategy, structure, and social science. Oxford: Oxford University Press. Williamson, Oliver E. (1971) 'The multidivisional hypothesis', in R. Marris and A. Wood (eds.), The corporate economy: Growth, competition, and innovative potential. London: Macmillan, pp. 343-86.
Muotoiltu: Tarkista oikeinkirjoitus ja kielioppi

Muotoiltu: Tarkista oikeinkirjoitus ja kielioppi

Muotoiltu: Väli Ennen: 0 pt, Riviväli: Kaksois

Muotoiltu: Tarkista oikeinkirjoitus ja kielioppi

Muotoiltu: Tarkista oikeinkirjoitus ja kielioppi

Muotoiltu: Tarkista oikeinkirjoitus ja kielioppi

Muotoiltu: Tarkista oikeinkirjoitus ja kielioppi

Muotoiltu: Tarkista oikeinkirjoitus ja kielioppi

Muotoiltu: Tarkista oikeinkirjoitus ja kielioppi

Muotoiltu: Tarkista oikeinkirjoitus ja kielioppi

Muotoiltu: Tarkista oikeinkirjoitus ja kielioppi

Muotoiltu: Tarkista oikeinkirjoitus ja kielioppi

Muotoiltu: Tarkista oikeinkirjoitus ja kielioppi

Muotoiltu: Tarkista oikeinkirjoitus ja kielioppi

Muotoiltu: Tarkista oikeinkirjoitus ja kielioppi

Muotoiltu: Tarkista oikeinkirjoitus ja kielioppi

Muotoiltu: Tarkista oikeinkirjoitus ja kielioppi

Muotoiltu: Tarkista oikeinkirjoitus ja kielioppi

Muotoiltu: Tarkista oikeinkirjoitus ja kielioppi

Muotoiltu: Fontti: Kursivoitu

Muotoiltu: Tarkista oikeinkirjoitus ja kielioppi

Muotoiltu: Fontti: Kursivoitu

Muotoiltu: Ei Korosta 
Wright, April L. and Zammuto, Raymond F. (2013) 'Wielding de willow: Processes of institutional change in English county cricket', Academy of Management Journal, 56(1): 308-30.

Vuori and Huy, 2015

$\underline{\text { Yin } 2013}$

Zimmermann, Hans-Jürgen $(-20014)$ Fuzzy set theory - and its applications.-Springer Science \& Business Media.

\section{Author biographies}

Matthias Kipping is Professor of Policy and Chair in Business History at the Schulich School of Business, York University in Toronto, Canada after previously holding positions in Spain and the UK. He has also been a visiting professor in France, Italy and Japan. Matthias obtained his doctorate from the Ludwig-Maximilians-University in Munich, Germany and Masters degrees from Harvard's Kennedy School of Government and the Sorbonne in Paris. His research is situated at the intersection of business history and management studies, a topic he has examined in various recent publications, including an article in the Academy of Management Annals in 2014 (jointly with Behlül Üsdiken). Other recent works include The Oxford Handbook of Management Consulting (OUP 2012; co-edited with Tim Clark) and Defining Management: Business Schools, Consultants, Media (Routledge 2016; co-authored with Lars Engwall and Behlül Üsdiken).
Muotoiltu: Tarkista oikeinkirjoitus ja kielioppi, Ei Korosta

Muotoiltu: Tarkista oikeinkirjoitus ja kielioppi, Ei Korosta

Muotoiltu: Fontti: Kursivoitu

Muotoiltu: Tarkista oikeinkirjoitus ja kielioppi, Ei Korosta

Muotoiltu: Tarkista oikeinkirjoitus ja kielioppi

Muotoiltu: Tarkista oikeinkirjoitus ja kielioppi, Ei Korosta

Muotoiltu: Tarkista oikeinkirjoitus ja kielioppi

Muotoiltu: Tarkista oikeinkirjoitus ja kielioppi

Muotoiltu: Tarkista oikeinkirjoitus ja kielioppi

Muotoiltu: Tarkista oikeinkirjoitus ja kielioppi

Muotoiltu: Fontti: Lihavoitu

Muotoiltu: Taso 1, Väli Ennen: 0 pt, Riviväli: Kaksois

Muotoiltu: Fontti: Lihavoitu Muotoiltu: Fontti: Lihavoitu,

Muotoiltu: Taso 1, Sisennys:Vasen: 0 $\mathrm{cm}$, Ensimmäinen rivi: $0 \mathrm{~cm}$, Väli

Ennen: 0 pt, Riviväli: Kaksois

Muotoiltu: Fontti: Kursivoitu

Muotoiltu: Fontti: Kursivoitu

Muotoiltu: Fontti: Kursivoitu 
Luha-Antti Lamberg is a Professor of Strategy and Economic History at the University of Iyväskylä - a position shared between the School of Business and the Department of History and Ethnology. His research has focused on history of/in strategy, especially in the contexts of mature industries and established firms. He has published research in the Academy of Management Review, Strategic Management Journal, the Journal of Management Studies, Industrial and Corporate Change, Academy of Management Learning \& Education, Organization Studies, Business \& Society, Human Relations, the European Management Lournal, the Scandinavian Economic History Review, as well as other journals. Prof. Lamberg won the Sloan Foundation's Industry Studies Best Paper Prize in 2008, the Carolyn Dexter Award in 2009 at the Academy of Management Conference, the Emerald Best Practical Implications Award in 2012, and the Outstanding Article of the Year in the Academy of Management Learning \& Education in 2015.

\section{AUTHORBIOS}

MATTHIAS KIPPING

$\Delta$

Prof. Juha-Antti Lamberg is a Professor of Strategy and Economic History at the University 4 of Ivväskylä (a position shared between the School of Business and the Department of History and Ethnology). His research has focused on history of/in strategy, especially in the contexts of mature industries and established firms. He has published research in the Academy of Management Review, Strategic Management Journal, the Journal of Management Studies, Industrial and Corporate Change, Academy of Management Learning
Muotoiltu: Fontti: Lihavoitu,

Muotoiltu: Fontti: Kursivoitu

Muotoiltu: Fontti: Kursivoitu

Muotoiltu: Fontti: Kursivoitu

Muotoiltu: Fontti: Kursivoitu

Muotoiltu: Fontti: Kursivoitu

Muotoiltu: Fontti: Kursivoitu

Muotoiltu: Fontti: Kursivoitu

Muotoiltu: Fontti: Kursivoitu

Muotoiltu: Fontti: Kursivoitu

Muotoiltu: Fontti: Kursivoitu

Muotoiltu: Fontti: Kursivoitu

Muotoiltu: Tarkista oikeinkirjoitus ja kielioppi

Muotoiltu: Tarkista oikeinkirjoitus ja kielioppi

Muotoiltu: EndNote Bibliography, Riviväli: Kaksois 
\& Education, Organization Studies, Business \& Society, Human Relations, the European

Management Journal, the Scandinavian Economic History Review, as well as other journals.

Prof. Lamberg won the Sloan Foundation's Industry Studies Best Paper Prize in 2008, the

Carolyn Dexter Award in 2009 at the Academy of Management Conference, the Emerald

Best Practical Implications Award in 2012, and the Outstanding Article of the Year at the

Academy of Management Learning \& Education in 2015.

Muotoiltu: Sisennys:Vasen: $0 \mathrm{~cm}$

Ensimmäinen rivi: $0 \mathrm{~cm}$, Väli Ennen: 0

pt, Riviväli: Kaksois 


\begin{tabular}{|c|c|c|}
\hline Sivu 34: [1] Muotoiltu & Matthias Kipping & 28.3.2016 11:46:00 \\
\hline \multicolumn{3}{|c|}{ Tarkista oikeinkirjoitus ja kielioppi } \\
\hline Sivu 34: [2] Muotoiltu & Matthias Kipping & 28.3.2016 11:46:00 \\
\hline \multicolumn{3}{|c|}{ Tarkista oikeinkirjoitus ja kielioppi } \\
\hline Sivu 34: [3] Muotoiltu & Matthias Kipping & 28.3.2016 11:46:00 \\
\hline \multicolumn{3}{|c|}{ Tarkista oikeinkirjoitus ja kielioppi } \\
\hline Sivu 34: [4] Muotoiltu & Matthias Kipping & 28.3.2016 11:46:00 \\
\hline \multicolumn{3}{|c|}{ Tarkista oikeinkirjoitus ja kielioppi } \\
\hline Sivu 34: [5] Muotoiltu & Matthias Kipping & 28.3.2016 11:46:00 \\
\hline \multicolumn{3}{|c|}{ Tarkista oikeinkirjoitus ja kielioppi } \\
\hline Sivu 34: [6] Muotoiltu & Matthias Kipping & 28.3.2016 11:46:00 \\
\hline \multicolumn{3}{|c|}{ Tarkista oikeinkirjoitus ja kielioppi } \\
\hline Sivu 34: [7] Muotoiltu & Matthias Kipping & 28.3.2016 11:46:00 \\
\hline \multicolumn{3}{|c|}{ Tarkista oikeinkirjoitus ja kielioppi } \\
\hline Sivu 34: [8] Muotoiltu & Matthias Kipping & 28.3.2016 11:46:00 \\
\hline \multicolumn{3}{|c|}{ Tarkista oikeinkirjoitus ja kielioppi } \\
\hline Sivu 34: [9] Muotoiltu & Matthias Kipping & 28.3.2016 11:46:00 \\
\hline \multicolumn{3}{|c|}{ Tarkista oikeinkirjoitus ja kielioppi } \\
\hline Sivu 34: [10] Muotoiltu & Matthias Kipping & 28.3.2016 11:49:00 \\
\hline \multicolumn{3}{|c|}{ Fontti: Kursivoitu, Tarkista oikeinkirjoitus ja kielioppi } \\
\hline Sivu 34: [11] Muotoiltu & Matthias Kipping & 28.3.2016 11:46:00 \\
\hline \multicolumn{3}{|c|}{ Tarkista oikeinkirjoitus ja kielioppi } \\
\hline Sivu 34: [12] Muotoiltu & Matthias Kipping & 28.3.2016 11:46:00 \\
\hline \multicolumn{3}{|c|}{ Tarkista oikeinkirjoitus ja kielioppi } \\
\hline Sivu 34: [13] Muotoiltu & Matthias Kipping & 28.3.2016 11:46:00 \\
\hline \multicolumn{3}{|c|}{ Tarkista oikeinkirjoitus ja kielioppi } \\
\hline Sivu 34: [14] Muotoiltu & Matthias Kipping & 28.3.2016 11:46:00 \\
\hline \multicolumn{3}{|c|}{ Tarkista oikeinkirjoitus ja kielioppi } \\
\hline Sivu 34: [15] Muotoiltu & Matthias Kipping & 28.3.2016 11:46:00 \\
\hline \multicolumn{3}{|c|}{ Tarkista oikeinkirjoitus ja kielioppi } \\
\hline Sivu 34: [16] Muotoiltu & Matthias Kipping & 28.3.2016 11:46:00 \\
\hline \multicolumn{3}{|c|}{ Tarkista oikeinkirjoitus ja kielioppi } \\
\hline Sivu 34: [17] Muotoiltu & Matthias Kipping & 28.3.2016 11:46:00 \\
\hline \multicolumn{3}{|c|}{ Tarkista oikeinkirjoitus ja kielioppi } \\
\hline Sivu 34: [18] Muotoiltu & Matthias Kipping & 28.3.2016 11:46:00 \\
\hline \multicolumn{3}{|c|}{ Tarkista oikeinkirjoitus ja kielioppi } \\
\hline Sivu 34: [19] Muotoiltu & Matthias Kipping & 28.3.2016 11:46:00 \\
\hline \multicolumn{3}{|c|}{ Tarkista oikeinkirjoitus ja kielioppi } \\
\hline Sivu 38: [20] Muotoiltu & Matthias Kipping & 28.3.2016 13:57:00 \\
\hline \multicolumn{3}{|l|}{ Fontti: Kursivoitu } \\
\hline Sivu 38: [21] Muotoiltu & Matthias Kipping & 28.3.2016 13:57:00 \\
\hline
\end{tabular}

Fontti: Kursivoitu 


\begin{tabular}{|c|c|c|}
\hline Sivu 38: [22] Muotoiltu & Matthias Kipping & 28.3.2016 14:06:00 \\
\hline \multicolumn{3}{|c|}{ englanti (Yhdysvallat) } \\
\hline Sivu 38: [23] Muotoiltu & Matthias Kipping & 28.3.2016 14:06:00 \\
\hline \multicolumn{3}{|c|}{ englanti (Yhdysvallat), Ei Korosta } \\
\hline Sivu 38: [24] Muotoiltu & Matthias Kipping & 28.3.2016 14:06:00 \\
\hline \multicolumn{3}{|c|}{ englanti (Yhdysvallat) } \\
\hline Sivu 38: [25] Muotoiltu & Matthias Kipping & 28.3.2016 14:06:00 \\
\hline \multicolumn{3}{|c|}{ Tarkista oikeinkirjoitus ja kielioppi } \\
\hline Sivu 38: [26] Muotoiltu & Matthias Kipping & 28.3.2016 14:06:00 \\
\hline \multicolumn{3}{|c|}{ Tarkista oikeinkirjoitus ja kielioppi } \\
\hline Sivu 38: [27] Muotoiltu & Matthias Kipping & 28.3.2016 14:06:00 \\
\hline \multicolumn{3}{|c|}{ Tarkista oikeinkirjoitus ja kielioppi } \\
\hline Sivu 38: [28] Muotoiltu & Matthias Kipping & 28.3.2016 14:06:00 \\
\hline \multicolumn{3}{|c|}{ Tarkista oikeinkirjoitus ja kielioppi } \\
\hline Sivu 38: [29] Muotoiltu & Matthias Kipping & 28.3.2016 14:06:00 \\
\hline \multicolumn{3}{|c|}{ Tarkista oikeinkirjoitus ja kielioppi } \\
\hline Sivu 38: [30] Muotoiltu & Matthias Kipping & 28.3.2016 14:06:00 \\
\hline \multicolumn{3}{|c|}{ Tarkista oikeinkirjoitus ja kielioppi } \\
\hline Sivu 38: [31] Muotoiltu & Matthias Kipping & 28.3.2016 14:06:00 \\
\hline \multicolumn{3}{|c|}{ englanti (Yhdysvallat), Ei Korosta } \\
\hline Sivu 38: [32] Muotoiltu & Matthias Kipping & 28.3.2016 14:06:00 \\
\hline \multicolumn{3}{|c|}{ englanti (Yhdysvallat), Ei Korosta } \\
\hline Sivu 38: [33] Muotoiltu & Matthias Kipping & 28.3.2016 14:06:00 \\
\hline \multicolumn{3}{|c|}{ englanti (Yhdysvallat), Ei Korosta } \\
\hline Sivu 38: [34] Muotoiltu & Matthias Kipping & 28.3.2016 14:06:00 \\
\hline \multicolumn{3}{|c|}{ englanti (Yhdysvallat), Ei Korosta } \\
\hline Sivu 38: [35] Muotoiltu & Matthias Kipping & 28.3.2016 14:06:00 \\
\hline \multicolumn{3}{|c|}{ englanti (Yhdysvallat), Ei Korosta } \\
\hline Sivu 38: [36] Muotoiltu & Matthias Kipping & 28.3.2016 14:06:00 \\
\hline \multicolumn{3}{|c|}{ englanti (Yhdysvallat), Ei Korosta } \\
\hline Sivu 38: [37] Muotoiltu & Matthias Kipping & 28.3.2016 14:06:00 \\
\hline \multicolumn{3}{|c|}{ englanti (Yhdysvallat), Ei Korosta } \\
\hline Sivu 38: [38] Muotoiltu & Matthias Kipping & 28.3.2016 14:12:00 \\
\hline \multicolumn{3}{|c|}{ englanti (Yhdysvallat), Ei Korosta } \\
\hline Sivu 38: [39] Muotoiltu & Matthias Kipping & 28.3.2016 14:12:00 \\
\hline \multicolumn{3}{|c|}{ Fontti: Ei Kursivoitu, englanti (Yhdysvallat), Ei Korosta } \\
\hline Sivu 38: [40] Muotoiltu & Matthias Kipping & 28.3.2016 14:12:00 \\
\hline \multicolumn{3}{|c|}{ englanti (Yhdysvallat), Ei Korosta } \\
\hline Sivu 38: [41] Muotoiltu & Matthias Kipping & 28.3.2016 14:12:00 \\
\hline \multicolumn{3}{|c|}{ englanti (Yhdysvallat), Ei Korosta } \\
\hline Sivu 38: [42] Muotoiltu & Matthias Kipping & 28.3.2016 14:06:00 \\
\hline
\end{tabular}


Ei Korosta

\begin{tabular}{|c|c|c|}
\hline Sivu 38: [43] Muotoiltu & Matthias Kipping & 28.3.2016 14:06:00 \\
\hline \multicolumn{3}{|c|}{ englanti (Yhdysvallat), Ei Korosta } \\
\hline Sivu 38: [44] Muotoiltu & Matthias Kipping & 28.3.2016 14:06:00 \\
\hline \multicolumn{3}{|c|}{ englanti (Yhdysvallat), Ei Korosta } \\
\hline Sivu 38: [45] Muotoiltu & Matthias Kipping & 28.3.2016 14:06:00 \\
\hline \multicolumn{3}{|c|}{ englanti (Yhdysvallat), Ei Korosta } \\
\hline Sivu 38: [46] Muotoiltu & Matthias Kipping & 28.3.2016 14:06:00 \\
\hline \multicolumn{3}{|c|}{ englanti (Yhdysvallat), Ei Korosta } \\
\hline Sivu 38: [47] Muotoiltu & Matthias Kipping & 28.3.2016 14:12:00 \\
\hline \multicolumn{3}{|c|}{ englanti (Yhdysvallat), Ei Korosta } \\
\hline Sivu 38: [48] Muotoiltu & Matthias Kipping & 28.3.2016 14:12:00 \\
\hline \multicolumn{3}{|c|}{ Fontti: Ei Kursivoitu, englanti (Yhdysvallat), Ei Korosta } \\
\hline Sivu 38: [49] Muotoiltu & Matthias Kipping & 28.3.2016 14:12:00 \\
\hline \multicolumn{3}{|c|}{ englanti (Yhdysvallat), Ei Korosta } \\
\hline Sivu 38: [50] Muotoiltu & Matthias Kipping & 28.3.2016 14:12:00 \\
\hline \multicolumn{3}{|c|}{ englanti (Yhdysvallat), Ei Korosta } \\
\hline Sivu 38: [51] Muotoiltu & Matthias Kipping & 28.3.2016 14:18:00 \\
\hline \multicolumn{3}{|c|}{ Tarkista oikeinkirjoitus ja kielioppi } \\
\hline Sivu 38: [52] Muotoiltu & Matthias Kipping & 28.3.2016 14:18:00 \\
\hline \multicolumn{3}{|c|}{ Tarkista oikeinkirjoitus ja kielioppi } \\
\hline Sivu 38: [53] Muotoiltu & Matthias Kipping & 28.3.2016 14:18:00 \\
\hline \multicolumn{3}{|c|}{ Tarkista oikeinkirjoitus ja kielioppi } \\
\hline Sivu 38: [54] Muotoiltu & Matthias Kipping & 28.3.2016 14:18:00 \\
\hline \multicolumn{3}{|c|}{ Tarkista oikeinkirjoitus ja kielioppi } \\
\hline Sivu 38: [55] Muotoiltu & Matthias Kipping & 28.3.2016 14:18:00 \\
\hline \multicolumn{3}{|c|}{ Tarkista oikeinkirjoitus ja kielioppi } \\
\hline Sivu 38: [56] Muotoiltu & Matthias Kipping & 28.3.2016 14:18:00 \\
\hline \multicolumn{3}{|c|}{ Tarkista oikeinkirjoitus ja kielioppi } \\
\hline Sivu 38: [57] Muotoiltu & Matthias Kipping & 28.3.2016 14:18:00 \\
\hline \multicolumn{3}{|c|}{ Tarkista oikeinkirjoitus ja kielioppi } \\
\hline Sivu 38: [58] Muotoiltu & Matthias Kipping & 28.3.2016 14:18:00 \\
\hline \multicolumn{3}{|c|}{ Tarkista oikeinkirjoitus ja kielioppi } \\
\hline Sivu 38: [59] Muotoiltu & Matthias Kipping & 28.3.2016 14:18:00 \\
\hline \multicolumn{3}{|c|}{ Tarkista oikeinkirjoitus ja kielioppi } \\
\hline Sivu 38: [60] Muotoiltu & Matthias Kipping & 28.3.2016 14:18:00 \\
\hline \multicolumn{3}{|c|}{ Tarkista oikeinkirjoitus ja kielioppi } \\
\hline Sivu 38: [61] Muotoiltu & Matthias Kipping & 28.3.2016 14:18:00 \\
\hline \multicolumn{3}{|c|}{ Tarkista oikeinkirjoitus ja kielioppi } \\
\hline Sivu 38: [62] Muotoiltu & Matthias Kipping & 28.3.2016 14:18:00 \\
\hline
\end{tabular}

Tarkista oikeinkirjoitus ja kielioppi 


\begin{tabular}{|c|c|c|}
\hline Sivu 38: [63] Muotoiltu & Matthias Kipping & 28.3.2016 14:18:00 \\
\hline \multicolumn{3}{|c|}{ Tarkista oikeinkirjoitus ja kielioppi } \\
\hline Sivu 40: [64] Muotoiltu & Matthias Kipping & 28.3.2016 14:18:00 \\
\hline \multicolumn{3}{|c|}{ Tarkista oikeinkirjoitus ja kielioppi } \\
\hline Sivu 40: [65] Muotoiltu & Matthias Kipping & 28.3.2016 14:18:00 \\
\hline \multicolumn{3}{|c|}{ Tarkista oikeinkirjoitus ja kielioppi } \\
\hline Sivu 40: [66] Muotoiltu & Matthias Kipping & 28.3.2016 14:18:00 \\
\hline \multicolumn{3}{|c|}{ Tarkista oikeinkirjoitus ja kielioppi } \\
\hline Sivu 40: [67] Muotoiltu & Matthias Kipping & 28.3.2016 14:18:00 \\
\hline \multicolumn{3}{|c|}{ Tarkista oikeinkirjoitus ja kielioppi } \\
\hline Sivu 40: [68] Muotoiltu & Matthias Kipping & 28.3.2016 14:18:00 \\
\hline \multicolumn{3}{|c|}{ Tarkista oikeinkirjoitus ja kielioppi } \\
\hline Sivu 40: [69] Muotoiltu & Matthias Kipping & 28.3.2016 14:18:00 \\
\hline \multicolumn{3}{|c|}{ Tarkista oikeinkirjoitus ja kielioppi } \\
\hline Sivu 40: [70] Muotoiltu & Matthias Kipping & 28.3.2016 14:18:00 \\
\hline \multicolumn{3}{|c|}{ Tarkista oikeinkirjoitus ja kielioppi } \\
\hline Sivu 40: [71] Muotoiltu & Matthias Kipping & 28.3.2016 14:18:00 \\
\hline \multicolumn{3}{|c|}{ Tarkista oikeinkirjoitus ja kielioppi } \\
\hline Sivu 40: [72] Muotoiltu & Matthias Kipping & 28.3.2016 14:18:00 \\
\hline \multicolumn{3}{|c|}{ Tarkista oikeinkirjoitus ja kielioppi } \\
\hline Sivu 40: [73] Muotoiltu & Matthias Kipping & 28.3.2016 14:18:00 \\
\hline \multicolumn{3}{|c|}{ Tarkista oikeinkirjoitus ja kielioppi } \\
\hline Sivu 40: [74] Muotoiltu & Matthias Kipping & 28.3.2016 14:18:00 \\
\hline \multicolumn{3}{|c|}{ Tarkista oikeinkirjoitus ja kielioppi } \\
\hline Sivu 40: [75] Muotoiltu & Matthias Kipping & 28.3.2016 14:18:00 \\
\hline \multicolumn{3}{|c|}{ Tarkista oikeinkirjoitus ja kielioppi } \\
\hline Sivu 40: [76] Muotoiltu & Matthias Kipping & 28.3.2016 14:18:00 \\
\hline \multicolumn{3}{|c|}{ Tarkista oikeinkirjoitus ja kielioppi } \\
\hline Sivu 40: [77] Muotoiltu & Matthias Kipping & 28.3.2016 14:18:00 \\
\hline \multicolumn{3}{|c|}{ Tarkista oikeinkirjoitus ja kielioppi } \\
\hline Sivu 40: [78] Muotoiltu & Matthias Kipping & 28.3.2016 14:18:00 \\
\hline \multicolumn{3}{|c|}{ Tarkista oikeinkirjoitus ja kielioppi } \\
\hline Sivu 40: [79] Muotoiltu & Matthias Kipping & 28.3.2016 14:18:00 \\
\hline \multicolumn{3}{|c|}{ Tarkista oikeinkirjoitus ja kielioppi } \\
\hline Sivu 40: [80] Muotoiltu & Matthias Kipping & 28.3.2016 14:18:00 \\
\hline \multicolumn{3}{|c|}{ Tarkista oikeinkirjoitus ja kielioppi } \\
\hline Sivu 40: [81] Muotoiltu & Matthias Kipping & 28.3.2016 14:18:00 \\
\hline \multicolumn{3}{|c|}{ Tarkista oikeinkirjoitus ja kielioppi } \\
\hline Sivu 40: [82] Muotoiltu & Matthias Kipping & 28.3.2016 14:18:00 \\
\hline \multicolumn{3}{|c|}{ Tarkista oikeinkirjoitus ja kielioppi } \\
\hline Sivu 40: [83] Muotoiltu & Matthias Kipping & 28.3.2016 14:18:00 \\
\hline
\end{tabular}

Tarkista oikeinkirjoitus ja kielioppi 


\begin{tabular}{|c|c|c|}
\hline Sivu 40: [84] Muotoiltu & Matthias Kipping & 28.3.2016 14:18:00 \\
\hline \multicolumn{3}{|c|}{ Tarkista oikeinkirjoitus ja kielioppi } \\
\hline Sivu 40: [85] Muotoiltu & Matthias Kipping & 28.3.2016 14:51:00 \\
\hline \multicolumn{3}{|c|}{ Fontti: Kursivoitu, Tarkista oikeinkirjoitus ja kielioppi } \\
\hline Sivu 40: [86] Muotoiltu & Matthias Kipping & 28.3.2016 14:18:00 \\
\hline \multicolumn{3}{|c|}{ Tarkista oikeinkirjoitus ja kielioppi } \\
\hline Sivu 40: [87] Muotoiltu & Matthias Kipping & 28.3.2016 14:18:00 \\
\hline \multicolumn{3}{|c|}{ Tarkista oikeinkirjoitus ja kielioppi } \\
\hline Sivu 41: [88] Muotoiltu & Matthias Kipping & 28.3.2016 14:58:00 \\
\hline \multicolumn{3}{|c|}{ Tarkista oikeinkirjoitus ja kielioppi } \\
\hline Sivu 41: [89] Muotoiltu & Matthias Kipping & 28.3.2016 14:58:00 \\
\hline \multicolumn{3}{|c|}{ Fontti: Ei Kursivoitu, Tarkista oikeinkirjoitus ja kielioppi } \\
\hline Sivu 41: [90] Muotoiltu & Matthias Kipping & 28.3.2016 14:58:00 \\
\hline \multicolumn{3}{|c|}{ Fontti: Ei Kursivoitu, Tarkista oikeinkirjoitus ja kielioppi } \\
\hline Sivu 41: [91] Muotoiltu & Matthias Kipping & 28.3.2016 14:58:00 \\
\hline \multicolumn{3}{|c|}{ Tarkista oikeinkirjoitus ja kielioppi } \\
\hline Sivu 41: [92] Muotoiltu & Matthias Kipping & 28.3.2016 14:58:00 \\
\hline \multicolumn{3}{|c|}{ Tarkista oikeinkirjoitus ja kielioppi } \\
\hline Sivu 41: [93] Muotoiltu & Matthias Kipping & 28.3.2016 14:58:00 \\
\hline \multicolumn{3}{|c|}{ Tarkista oikeinkirjoitus ja kielioppi } \\
\hline Sivu 41: [94] Muotoiltu & Matthias Kipping & 28.3.2016 14:58:00 \\
\hline \multicolumn{3}{|c|}{ Tarkista oikeinkirjoitus ja kielioppi } \\
\hline Sivu 41: [95] Muotoiltu & Matthias Kipping & 28.3.2016 14:58:00 \\
\hline \multicolumn{3}{|c|}{ Tarkista oikeinkirjoitus ja kielioppi } \\
\hline Sivu 41: [96] Muotoiltu & Matthias Kipping & 28.3.2016 14:58:00 \\
\hline \multicolumn{3}{|c|}{ Tarkista oikeinkirjoitus ja kielioppi } \\
\hline Sivu 41: [97] Muotoiltu & Matthias Kipping & 28.3.2016 14:58:00 \\
\hline \multicolumn{3}{|c|}{ Tarkista oikeinkirjoitus ja kielioppi } \\
\hline Sivu 41: [98] Muotoiltu & Matthias Kipping & 28.3.2016 14:58:00 \\
\hline \multicolumn{3}{|c|}{ Tarkista oikeinkirjoitus ja kielioppi } \\
\hline Sivu 41: [99] Muotoiltu & Matthias Kipping & 28.3.2016 14:58:00 \\
\hline \multicolumn{3}{|c|}{ Tarkista oikeinkirjoitus ja kielioppi } \\
\hline Sivu 41: [100] Muotoiltu & Matthias Kipping & 28.3.2016 14:58:00 \\
\hline \multicolumn{3}{|c|}{ Tarkista oikeinkirjoitus ja kielioppi } \\
\hline Sivu 41: [101] Muotoiltu & Matthias Kipping & 28.3.2016 14:58:00 \\
\hline \multicolumn{3}{|c|}{ Tarkista oikeinkirjoitus ja kielioppi } \\
\hline Sivu 41: [102] Muotoiltu & Matthias Kipping & 28.3.2016 14:58:00 \\
\hline \multicolumn{3}{|c|}{ Tarkista oikeinkirjoitus ja kielioppi } \\
\hline Sivu 41: [103] Muotoiltu & Matthias Kipping & 28.3.2016 14:58:00 \\
\hline \multicolumn{3}{|c|}{ Tarkista oikeinkirjoitus ja kielioppi } \\
\hline Sivu 41: [104] Muotoiltu & Matthias Kipping & $28.3 .201614: 58: 00$ \\
\hline
\end{tabular}


Tarkista oikeinkirjoitus ja kielioppi

Sivu 41: [105] Muotoiltu

Tarkista oikeinkirjoitus ja kielioppi

Sivu 41: [106] Muotoiltu

Tarkista oikeinkirjoitus ja kielioppi

Sivu 41: [107] Muotoiltu

Tarkista oikeinkirjoitus ja kielioppi

Sivu 41: [108] Muotoiltu

Tarkista oikeinkirjoitus ja kielioppi

Sivu 41: [109] Muotoiltu

Matthias Kipping

28.3.2016 15:03:00

Fontti: Kursivoitu, Tarkista oikeinkirjoitus ja kielioppi

\begin{tabular}{|c|c|c|}
\hline Sivu 41: [110] Muotoiltu & Matthias Kipping & 28.3.2016 14:58:00 \\
\hline \multicolumn{3}{|c|}{ Tarkista oikeinkirjoitus ja kielioppi } \\
\hline Sivu 41: [111] Muotoiltu & Matthias Kipping & 28.3.2016 14:58:00 \\
\hline \multicolumn{3}{|c|}{ Tarkista oikeinkirjoitus ja kielioppi } \\
\hline Sivu 41: [112] Muotoiltu & Matthias Kipping & 28.3.2016 14:58:00 \\
\hline \multicolumn{3}{|c|}{ Tarkista oikeinkirjoitus ja kielioppi } \\
\hline Sivu 41: [113] Muotoiltu & Matthias Kipping & 28.3.2016 14:58:00 \\
\hline \multicolumn{3}{|c|}{ Tarkista oikeinkirjoitus ja kielioppi } \\
\hline Sivu 41: [114] Muotoiltu & Matthias Kipping & 28.3.2016 14:58:00 \\
\hline \multicolumn{3}{|c|}{ Tarkista oikeinkirjoitus ja kielioppi } \\
\hline Sivu 41: [115] Muotoiltu & Matthias Kipping & 28.3.2016 14:58:00 \\
\hline \multicolumn{3}{|c|}{ Tarkista oikeinkirjoitus ja kielioppi } \\
\hline Sivu 41: [116] Muotoiltu & Matthias Kipping & 28.3.2016 14:58:00 \\
\hline \multicolumn{3}{|c|}{ Tarkista oikeinkirjoitus ja kielioppi } \\
\hline Sivu 41: [117] Muotoiltu & Matthias Kipping & 28.3.2016 14:58:00 \\
\hline \multicolumn{3}{|c|}{ Tarkista oikeinkirjoitus ja kielioppi } \\
\hline Sivu 41: [118] Muotoiltu & Matthias Kipping & 28.3.2016 15:04:00 \\
\hline \multicolumn{3}{|c|}{ Tarkista oikeinkirjoitus ja kielioppi } \\
\hline Sivu 41: [119] Muotoiltu & Matthias Kipping & 28.3.2016 15:04:00 \\
\hline \multicolumn{3}{|c|}{ Tarkista oikeinkirjoitus ja kielioppi } \\
\hline Sivu 41: [120] Muotoiltu & Matthias Kipping & 28.3.2016 15:04:00 \\
\hline \multicolumn{3}{|c|}{ Tarkista oikeinkirjoitus ja kielioppi } \\
\hline Sivu 41: [121] Muotoiltu & Matthias Kipping & 28.3.2016 15:04:00 \\
\hline \multicolumn{3}{|c|}{ Tarkista oikeinkirjoitus ja kielioppi } \\
\hline Sivu 41: [122] Muotoiltu & Matthias Kipping & 28.3.2016 15:04:00 \\
\hline \multicolumn{3}{|c|}{ Tarkista oikeinkirjoitus ja kielioppi } \\
\hline Sivu 42: [123] Muotoiltu & Matthias Kipping & 28.3.2016 17:30:00 \\
\hline \multicolumn{3}{|c|}{ Väli Ennen: 0 pt, Riviväli: Kaksois } \\
\hline Sivu 42: [124] Muotoiltu & Matthias Kipping & 28.3.2016 15:26:00 \\
\hline
\end{tabular}

englanti (Yhdysvallat), Ei Korosta 


\begin{tabular}{|c|c|c|}
\hline Sivu 42: [125] Muotoiltu & Matthias Kipping & 28.3.2016 15:26:00 \\
\hline \multicolumn{3}{|c|}{ englanti (Yhdysvallat), Ei Korosta } \\
\hline Sivu 42: [126] Muotoiltu & Matthias Kipping & 28.3.2016 15:26:00 \\
\hline \multicolumn{3}{|c|}{ englanti (Yhdysvallat), Ei Korosta } \\
\hline Sivu 42: [127] Muotoiltu & Matthias Kipping & 28.3.2016 15:26:00 \\
\hline \multicolumn{3}{|c|}{ englanti (Yhdysvallat), Ei Korosta } \\
\hline Sivu 42: [128] Muotoiltu & Matthias Kipping & 28.3.2016 15:29:00 \\
\hline \multicolumn{3}{|c|}{ englanti (Yhdysvallat), Ei Korosta } \\
\hline Sivu 42: [129] Muotoiltu & Matthias Kipping & 28.3.2016 15:29:00 \\
\hline \multicolumn{3}{|c|}{ Fontti: Ei Kursivoitu, englanti (Yhdysvallat), Ei Korosta } \\
\hline Sivu 42: [130] Muotoiltu & Matthias Kipping & 28.3.2016 15:29:00 \\
\hline \multicolumn{3}{|c|}{ englanti (Yhdysvallat), Ei Korosta } \\
\hline Sivu 42: [131] Muotoiltu & Matthias Kipping & 28.3.2016 15:29:00 \\
\hline \multicolumn{3}{|c|}{ englanti (Yhdysvallat), Ei Korosta } \\
\hline Sivu 43: [132] Muotoiltu & Matthias Kipping & 28.3.2016 15:34:00 \\
\hline
\end{tabular}

Fontti: Ei Kursivoitu, englanti (Yhdysvallat), Tarkista oikeinkirjoitus ja kielioppi, Ei Korosta

Sivu 43: [133] Muotoiltu Matthias Kipping

englanti (Yhdysvallat), Tarkista oikeinkirjoitus ja kielioppi, Ei Korosta

\begin{tabular}{|c|c|c|}
\hline Sivu 43: [134] Muotoiltu & Matthias Kipping & 28.3.2016 15:34:00 \\
\hline \multicolumn{3}{|c|}{ englanti (Yhdysvallat), Tarkista oikeinkirjoitus ja kielioppi, Ei Korosta } \\
\hline Sivu 43: [135] Muotoiltu & Matthias Kipping & 28.3.2016 15:26:00 \\
\hline \multicolumn{3}{|c|}{ Tarkista oikeinkirjoitus ja kielioppi } \\
\hline Sivu 43: [136] Muotoiltu & Matthias Kipping & 28.3.2016 15:26:00 \\
\hline \multicolumn{3}{|c|}{ Tarkista oikeinkirjoitus ja kielioppi } \\
\hline Sivu 43: [137] Muotoiltu & Matthias Kipping & 28.3.2016 15:26:00 \\
\hline \multicolumn{3}{|c|}{ Tarkista oikeinkirjoitus ja kielioppi } \\
\hline Sivu 43: [138] Muotoiltu & Matthias Kipping & 28.3.2016 15:26:00 \\
\hline \multicolumn{3}{|c|}{ Tarkista oikeinkirjoitus ja kielioppi } \\
\hline Sivu 43: [139] Muotoiltu & Matthias Kipping & 28.3.2016 15:26:00 \\
\hline \multicolumn{3}{|c|}{ Tarkista oikeinkirjoitus ja kielioppi } \\
\hline Sivu 43: [140] Muotoiltu & Matthias Kipping & 28.3.2016 15:26:00 \\
\hline \multicolumn{3}{|c|}{ Tarkista oikeinkirjoitus ja kielioppi } \\
\hline Sivu 43: [141] Muotoiltu & Matthias Kipping & 28.3.2016 15:26:00 \\
\hline \multicolumn{3}{|c|}{ Tarkista oikeinkirjoitus ja kielioppi } \\
\hline Sivu 43: [142] Muotoiltu & Matthias Kipping & 28.3.2016 15:26:00 \\
\hline \multicolumn{3}{|c|}{ Tarkista oikeinkirjoitus ja kielioppi } \\
\hline Sivu 43: [143] Muotoiltu & Matthias Kipping & 28.3.2016 15:26:00 \\
\hline \multicolumn{3}{|c|}{ Tarkista oikeinkirjoitus ja kielioppi } \\
\hline Sivu 43: [144] Muotoiltu & Matthias Kipping & 28.3.2016 15:26:00 \\
\hline \multicolumn{3}{|c|}{ Tarkista oikeinkirjoitus ja kielioppi } \\
\hline Sivu 43: [145] Muotoiltu & Matthias Kipping & 28.3.2016 15:41:00 \\
\hline
\end{tabular}


Fontti: Kursivoitu, Tarkista oikeinkirjoitus ja kielioppi

\begin{tabular}{|c|c|c|}
\hline Sivu 43: [146] Muotoiltu & Matthias Kipping & 28.3.2016 15:26:00 \\
\hline \multicolumn{3}{|c|}{ Tarkista oikeinkirjoitus ja kielioppi } \\
\hline Sivu 43: [147] Muotoiltu & Matthias Kipping & 28.3.2016 15:26:00 \\
\hline \multicolumn{3}{|c|}{ Tarkista oikeinkirjoitus ja kielioppi } \\
\hline Sivu 43: [148] Muotoiltu & Matthias Kipping & 28.3.2016 15:26:00 \\
\hline \multicolumn{3}{|c|}{ Tarkista oikeinkirjoitus ja kielioppi } \\
\hline Sivu 43: [149] Muotoiltu & Matthias Kipping & 28.3.2016 15:26:00 \\
\hline \multicolumn{3}{|c|}{ Tarkista oikeinkirjoitus ja kielioppi } \\
\hline Sivu 43: [150] Muotoiltu & Matthias Kipping & 28.3.2016 15:26:00 \\
\hline \multicolumn{3}{|c|}{ Tarkista oikeinkirjoitus ja kielioppi } \\
\hline Sivu 43: [151] Muotoiltu & Matthias Kipping & 28.3.2016 15:26:00 \\
\hline \multicolumn{3}{|c|}{ Tarkista oikeinkirjoitus ja kielioppi } \\
\hline Sivu 43: [152] Muotoiltu & Matthias Kipping & 28.3.2016 15:26:00 \\
\hline \multicolumn{3}{|c|}{ Tarkista oikeinkirjoitus ja kielioppi } \\
\hline Sivu 43: [153] Muotoiltu & Matthias Kipping & 28.3.2016 15:26:00 \\
\hline \multicolumn{3}{|c|}{ Tarkista oikeinkirjoitus ja kielioppi } \\
\hline Sivu 43: [154] Muotoiltu & Matthias Kipping & 28.3.2016 15:26:00 \\
\hline \multicolumn{3}{|c|}{ Tarkista oikeinkirjoitus ja kielioppi } \\
\hline Sivu 43: [155] Muotoiltu & Matthias Kipping & 28.3.2016 15:26:00 \\
\hline \multicolumn{3}{|c|}{ Tarkista oikeinkirjoitus ja kielioppi } \\
\hline Sivu 43: [156] Muotoiltu & Matthias Kipping & 28.3.2016 15:26:00 \\
\hline \multicolumn{3}{|c|}{ Tarkista oikeinkirjoitus ja kielioppi } \\
\hline Sivu 43: [157] Muotoiltu & Matthias Kipping & 28.3.2016 15:26:00 \\
\hline \multicolumn{3}{|c|}{ Tarkista oikeinkirjoitus ja kielioppi } \\
\hline Sivu 43: [158] Muotoiltu & Matthias Kipping & 28.3.2016 15:26:00 \\
\hline \multicolumn{3}{|c|}{ Tarkista oikeinkirjoitus ja kielioppi } \\
\hline Sivu 43: [159] Muotoiltu & Matthias Kipping & 28.3.2016 15:26:00 \\
\hline \multicolumn{3}{|c|}{ Tarkista oikeinkirjoitus ja kielioppi, Ei Korosta } \\
\hline Sivu 43: [160] Muotoiltu & Matthias Kipping & 28.3.2016 17:30:00 \\
\hline
\end{tabular}

Taso 1, Väli Ennen: 0 pt, Riviväli: Kaksois 